\title{
WASTE AND WASTED LANDSCAPES: FOCUS ON ABANDONED INDUSTRIAL AREAS
}

\author{
Silvia lodice ${ }^{1, \star}$ and Pasquale De Toro ${ }^{2}$ \\ ${ }^{1}$ Joint Research Centre (JRC), European Commission, Territorial Development Unit (B.3), via E. Fermi 2749, Ispra (VA), Italy \\ ${ }^{2}$ Department of Architecture, University of Naples Federico II (UNINA), via Forno Vecchio 36, 80134 Napoli, Italy
}

Article Info:
Received:
30 April 2020
Revised:
2 June 2020
Accepted:
12 June 2020
Available online:
23 July 2020
Keywords:
Wasted landscapes
Abandoned industrial areas
Territorial regeneration
Life cycle assessment
Urban metabolism

\section{INTRODUCTION}

An ecosystem "is defined as an area, place or environment where organisms interact with the physical and chemical environment" (Chatzinikolaou et al., 2018, p. 43). In this perspective, cities can be seen as urban ecosystems, i.e. systems formed by the combination of people and nature, where biophysical and social factors regularly interact in a resilient and sustained manner and where different spatial, temporal and organizational scales exist (Redman et al., 2004). There is a variety of definitions of this concept, for example Tansley (1935) defines urban ecosystems as a combination of physical factors forming what we call the "environment", while Threlfall and Kendal (2018, p. 248) express the concept according to which "urban ecosystems contain a myriad of natural, constructed and hybrid spaces, where the combination of each is unique in every city and town".

Like any ecosystem form, cities are also nodes of consumption of energy and material as well as production of residuals (Rees and Wackernagel, 1996) and in order to understand their functioning, it is necessary to focus on the material, energy and information flows that sustain the human population (Rees, 1997). Urban ecosystem are characterized by a heterotrophic nature because of their dependence on external sources of energy and they are also energy-intensive entities (Collins, 2000).

About $72 \%$ of the European population is concentrated in cities; therefore, in order to support their functioning, vast amounts of energy, food, water and other kind of goods are used, generating as well huge quantities of waste (Phillis et al., 2017). It is possible to say that urban ecosystems are complex and open systems closely linked with their surroundings through metabolic exchanges of energy and material flows and information circulation (Su et al., 2012) and as a consequence they are entities characterized by their own Urban Metabolism (UM) (Marx, 1909; Wolman, 1965; Kennedy et al., 2007). According to Broto et al. (2012), UM links material flows with social and ecological processes and it is necessary to take into account the possibility to modify the actual patterns of consumption and production towards more sustainable schemes.

Definitely, through an analogy between cities and metabolic processes of organisms, it is possible to understand the functioning and the development of a city by the consideration of the inputs, the outputs and the storage of different resources, mainly represented by energy, water, nutrients, materials, and wastes (Maranghi et al., 2020). According to Mostafavi et al. (2014), through the analysis and quantification of the materials that circulate within a city, it is possible to assess the impacts of urban development and to perform a multidimensional assessment of sustainability (Beloin-Saint-Pierre et al., 2017). Furthermore, the actual prevailing linear UM considers the city as an urban machine, consuming unlimited resources and producing waste to dispose of (Gasparrini, 2013), determining the necessity to rely no longer on this kind of model. 
Three main typologies of metabolic flows can be identified within a city (Minx et al., 2010):

- Direct extractions and releases, that are resources directly extracted and wastes and emissions released;

- ilmports and exports, that are different products that can be imported or exported in and out of the urban ecosystem;

Indirect flows associated with imports and exports, such as resources indirectly extracted and emissions and waste products indirectly released.

Moreover, UM can be examined at different scales: global UM studies analyze the global antroposphere, while there are studies at the national or regional scale as well as at the urban and local dimension ( $\mathrm{Li}$ and Kwan, 2017). Definitely, UM determines the necessity to adopt a flow perspective on urban ecosystems (Dijst et al., 2018).

Having defined urban ecosystems, the aim of the present paper is to focus on abandoned portions of these ecosystems, i.e. wasted areas produced by the results of UM. In the subsequent sections, the concepts of territorial life cycle and wasted landscapes are introduced, presenting a methodology to spatially identify former industrial areas in a portion of the Metropolitan Area of Naples (MAN). In a multi-scale perspective, abandoned industrial areas are connected to the production of Construction and Demolition Waste (CDW), linking waste landscapes and waste flows.

\section{THE CYCLICAL NATURE OF URBAN ECO- SYSTEMS}

\subsection{Renewable cities: the concept of territorial life cycle}

The concept of life cycle refers to all the phases that distinguish the life of an element, and in the present case the territorial system is taken into account. Urban ecosystem, being a concentration of environmental, social and economic resources and services, evolve according to the form of governance to which their territory is subjected. A set of interconnected phases strictly linked to a system of resources and performances that characterize the territorial functioning, determine the end of a life cycle and the rise of a new phase. This concept can be referred to a particular temporal scenario in which, it is possible to find three different processes (Torricelli, 2015a):

\section{- Settlement processes;}

- Processes of use and consumption of resources, equipment and services;

- Processes of production and consumption of goods destined more or less to the territory.

These processes result in the generation of environmental flows and social relations linked to the territorial activities. In this perspective, a territorial portion does not have the possibility to grow endlessly, but when the system of its resources is exhausted, this area will overcome an involution phase until a new balance is found, i.e. a new life cycle is started (Zucchetti, 2008). An urban ecosys- tem, like all complex autopoietic systems, tries to keep its identity intact thanks to flows of matter and energy and the end of a territorial life cycle does not mean that the territory interrupts its functioning, because this process is continuous.

Different social, economic and multidimensional factors are responsible for the evolution of the territorial life cycle. However, this concept is not totally new: for example, it is possible to think about the slogan developed by the American architect William MC Donough and the chemist Michael Braungart "Cradle to Cradle"(McDonough and Braungart, 2002), which is based on the application of biological criteria to industrial processes, that, passing from one state to another, can generate new life cycles.

In the present paper, this concept is based on the possibility of generating new life cycles for abandoned portions of the territory, giving rise to recycling strategies for building, urban and environmental resources (Bocchi et al., 2013), determining to the so-called "hyper-cycle, i.e. a reactivation of a certain life cycle. Another interesting concept is that of the so called Cityforming @ ${ }^{\circ}$, proposed by Carta (2016), that is a design protocol capable of reactivating the metabolism of an area starting from its latent regenerative components, activating multiple cycles of increasing intensity to create a new sustainable urban ecosystem over time. The application of this protocol is able to reactivate the inactive cycles, but also to reconnect the interrupted ones or to activate new ones, more suited to the new identity of the places. Carta (2016) identifies three main life cycle phases:

- The colonization phase, in which some new functions are identified or some buildings are recovered; the latter are like stamina cells. This phase can also comprise the removal of some infrastructural or environmental detractors, facilitating the reconstitution of some ecological networks;

- The consolidation phase, that acts on the new ecosystem through the grafting of some more valuable functions, able to generate profits, increasing the attractiveness of the area;

- The development phase, in which the new metabolism of the area is able to generate new urban value.

Definitely, the life cycle phases of the territory can be generated by different causes, spontaneous or induced. The latter generally intervene on those portions of the territory whose life cycles, almost completely exhausted, require the start of strategic regeneration actions capable of giving new life to the territory. If city are like living organisms, through the start of a new life cycle it is possible to proliferate and hybridize the surrounding tissues, transforming a group of undifferentiated cells into new organs and new connective tissues (Carta, 2013). If the concept of life cycle can be associated to that of change, a city is like a body in constant transformation (McDonough and Braungart, 2002) and can be seen as a renewable resource.

In conclusion, the starting point of the present work is the assumption that the city does not follow an unmodifiable biological path, but has the ability to regenerate itself, 
overcoming a life cycle and decline phase, reinterpreting its components (Gabbianelli, 2013).

\subsection{Wasted landscapes}

As already specified, "cities are not static objects, but active arenas marked by continuous energy flows and transformations of which landscapes and buildings and other hard parts are not permanent structures but transitional manifestations" (Berger, 2006b, p. 203). According to Lynch and Southworth (1990, p.146), waste "is worthless or unused for human purpose. It is a lessening of something without useful result; it is loss and abandonment, decline, separation and death. It is the spent and valueless material left after some act of production or consumption, but can also refer to any used thing: garbage, trash, litter, junk, impurity and dirt. There are waste things, waste lands, waste time and wasted lives".

Similarly, Berger (2006, p. 203) states that "contemporary modes of industrial production driven by economical and consumerist influences contribute to urbanization and the formation of waste landscapes - meaning actual waste (such as municipal solid waste, sewage, scrap metal, etc.), wasted places (such as abandoned and/or contaminated sites) or wasteful places (such as oversized parking lots or duplicate big-box retail venues)".

Waste in its spatial connotation is the outcome of urban processes that characterize the activities of the supply chain, i.e. the set of activities that feed the life cycle of a product from the phase of extraction of raw materials up to the disposal of waste materials. The supply chain, in other words, represents the distribution chain of a product or service from the supplier to the customer, starting from the raw materials necessary for its realization, then moving on to the realization of the product, and subsequently to the phases of management and distribution to the customer, which carries out the consumption phase. Each single phase determines the production of waste products, and tracing the waste streams starting from the production phase of the products, allows to analyze the consumption patterns and to identify better paths to be taken, facilitating the transition from the linear economy model to the circular one.

In this perspective, urban ecosystems are characterized by the presence of portions of territory at the end of their life cycle, i.e. wasted landscapes or wastescapes (Amenta and Attademo, 2016; Amenta and Van Timmermen, 2018). This concept, has been analysed in the Horizon 2020 Project REPAiR - Resource Management in Peri-urban Areas: Going Beyond Urban Metabolism¹, that proposes an association between waste products and wasted landscapes. The concept of wastescapes derives from that of drosscapes coined by Berger (2006), i.e. wasted landscapes that are an outcome of metabolic processes. Drosscapes "accumulate in the wake of the socio - and spatio - economic processes of deindustrialization, post-Fordism and technological innovation" and they "are located in the declining, neglected and deindustrializing areas of cities" (Berger, 2006, p. 239). Consequently, there are physical components of the urban structure that lose their function and, at the same time, the economic and so- cial recognition of their usefulness: what occurs is the definitive or temporary suspension of a determined use of a certain space, with its consequent abandonment, the subsequent re-use, and more rarely and more distant in time its full replacement.

Wastescapes are an inevitable result of the processes of economic growth that produce waste and emissions that damage land, water, fields, but also buildings and infrastructures. Therefore, the flows of matter and energy and those of waste that feed or come from the activities of the supply chain, respectively, are also able to shape the territory in its physicality. This generates the development of portions of territory that are no longer able to provide goods and services and, finding themselves at the end of their life cycle, they are like "waiting spaces" or terrain vague. The activation of new urban regeneration processes may be able to give new functions to these portions of territory and to reconnect them to the surrounding urban fabric. This means that the real challenge is to integrate these portions of land into the functioning of urban ecosystems (Berger, 2007), turning useless matter into useful matter, as it happens in the waste recycling system (Erz, 1992; Strasser, 1992), avoiding further land consumption. The disuse can be understood as a "natural" phase of the life cycle of the functions and spaces predisposed to welcome them (Baiocco et al., 2017). This vision determines the consideration of urban ecosystems as endowed with a metabolism capable of digesting, assimilate and feed the succession of cycles of production and where space is always small with respect to the quantity of flows (economic and human) that cross it.

Definitely, waste can be interpreted as a natural and unavoidable component of an evolving and dynamic urban ecosystem and represents an indicator of its healthy growth (Berger, 2007).

REPAiR projects identifies $5+1$ categories of wastescapes that are grouped in drosscapes and operational infrastructure of waste, the latter represented by the plants dedicated to Waste Management (WM) (Geldermans et al., 2018):

\section{DROSSCAPES}

1. Degraded land (W1)

2. Degraded water and connected areas (W2)

3. Declining fields (W3)

4. Settlements and buildings in crisis (W4)

5. "Dross" of facilities and infrastructures (W5) $+$

\section{OPERATIONAL INFRASTRUCTURE OF WASTE (W6)}

\subsubsection{How to map wastescapes? A spatial methodology for their identification}

For the territorial identification of wastescapes, it is necessary to define a precise spatial methodology of analysis that could be systematically replicable. The flows of matters and energy that cross the territory, allowing the carrying out of the activities of the supply chain, cause not only emissions and waste flows, but they also physically shape the territory. There is, indeed, a strict link between territorial processes and wastescapes determination, 
which can be considered the spatial result of UM together with impacts at micro, meso and macro scale. Therefore, the metabolic activities of extraction, production, distribution and consumption that define the supply chain and the activity of Waste Management (WM), affect resources, but simultaneously are able to generate Land Use Functions (LUF) and to provide environmental, social and economic services as well. In the same time, they alter the territorial performances, generating multidimensional impacts and in addition a particular form of spatial impact known as wastescape (Figure 1).

The general idea for the wastescapes characterization methodology is that of aggregating increasingly complex information up to the definition of performance indicators . The spatial organization of a city, as well as its infrastructural system, affect the resources used to support human activities and therefore its level of environmental pressure on the regional and global environment (Alberti and Susskind, 1996).

The starting point is the concept that these metabolic activities are powered by resources (EEA, 2015) that feed the processes that act on the territory and generate in the meantime environmental, social and economic performances. The European Commission's Thematic Strategy on the Sustainable Use of Natural Resources (European Commission, 2005) states that European Economies depend on natural resources that can be defined as anything that occurs in nature that has the possibility to be used for economic production or consumption (OECD, 2010) or also that can be used for producing something else (UNEP, 2011). Furthermore, spatial planning in general is able to condition the use of resources, influencing as well the con- sumption pattern of an urban ecosystem, because the spatial form of cities has a long-standing impact on the daily resources needed (Dijst, 2013). Consequently, urban ecosystems are undergoing multiple and often contradictory changes from expansion to de-industrialization and land abandonment (McPhearson et al., 2016).

According to European Commission (2005), natural resources that feed European economies are composed by:

- Raw materials, such as minerals, biomass and biological resources;

- Environmental media such as air, water and soil;

- Flow resources such as wind, geothermal, tidal and solar energy;

- Space (land area).

The life cycle of the supply chain processes and the available resources allow interpreting the territory as a system of use functions (Loiseau et al., 2014; Torricelli and Gargari, 2015).

The system of interpretation for the wastescapes characterization and spatial mapping is formed by four main steps which follow each other cyclically (Figure 2):

\section{Pattern; \\ - Process; \\ - Driver; \\ - Effect.}

As far as the pattern is concerned, this refers to the spatial and territorial organization of the area under analysis and of its characterizing geographies, in terms of combination between land cover, land use and land use func-

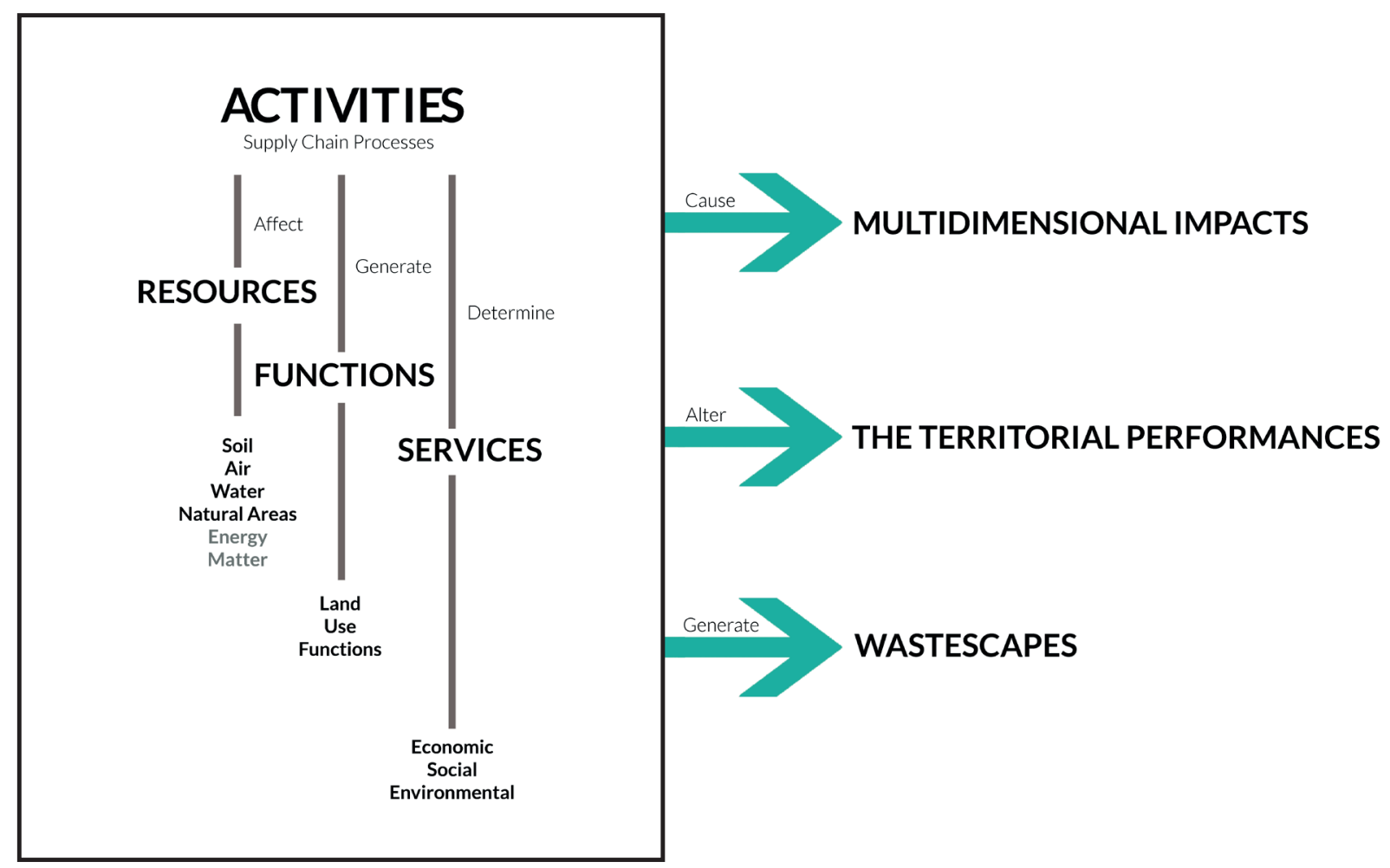

FIGURE 1: Activities in the supply chain processes and their consequences². 


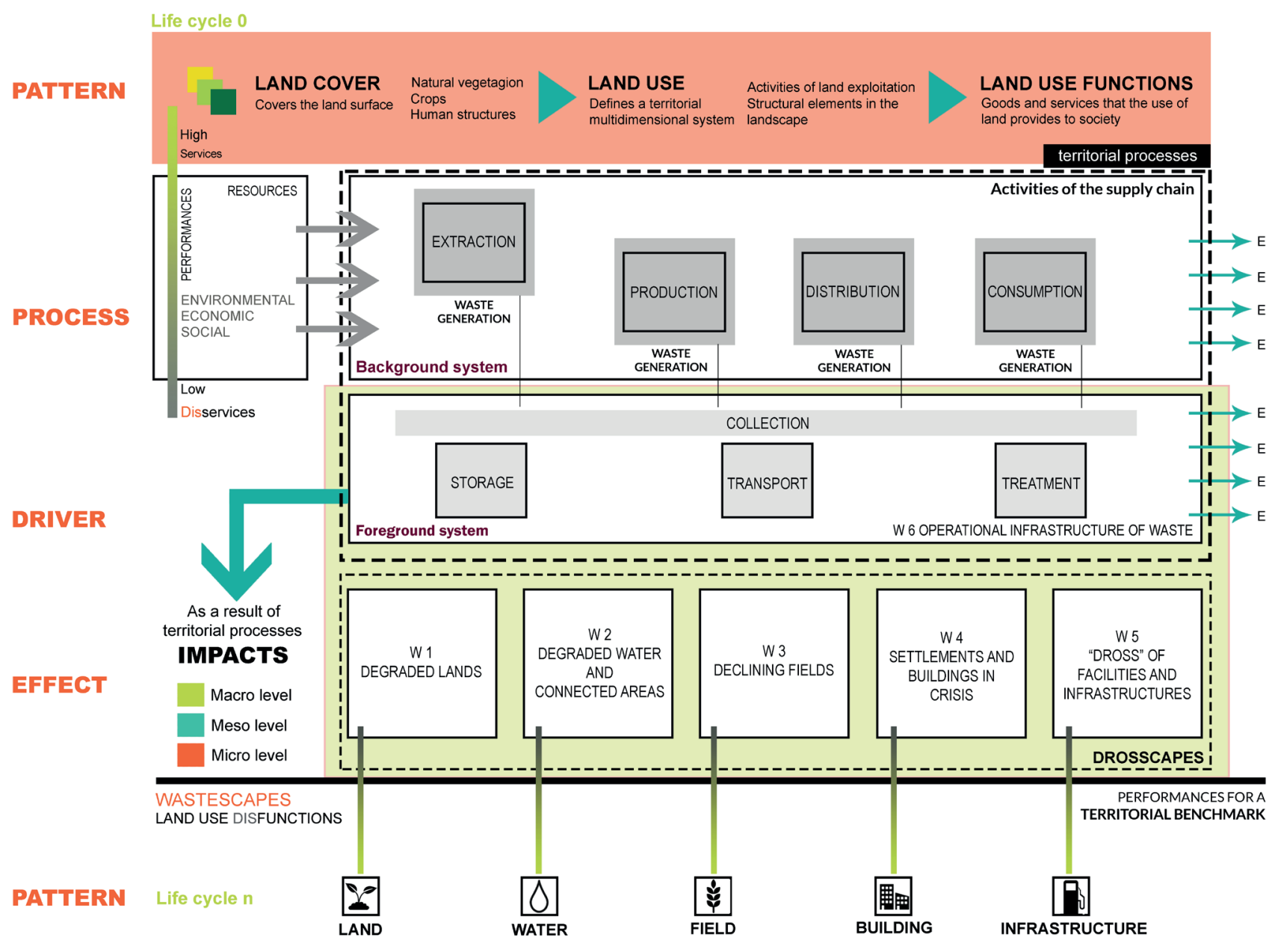

FIGURE 2: Wastescapes characterization model.

tions. The latters allow defining the main features of the area under analysis from a physical and human perspective (Geldermans et al., 2017). As a matter of fact, "form the spatial patterns of the built, infrastructural, and embedded biotic components of cities - is a crucial component of urban structure" and this link between urban structure and its functioning provides a new way of analyzing urban ecosystems patterns and processes (McPhearson et al., 2016, p. 206).

Secondly, wastescapes are the results of the territorial processes and therefore they could be analyzed according to each single activity of the supply chain that influences flows and stocks within the urban ecosystem (Dijst et al., 2018).

Once chosen the activity to analyze, it is necessary to define the land cover that hosts this activity and the subsequent land use. On the one hand, the first represents the observed (bio)physical cover of the earth's surface (Di Gregorio, 2005) and it is formed by three main categories: natural vegetation, crops and human structure, each one generating a certain number of sub-categories. The main reference for the land cover is represented by the Corine Land Cover (CLC) elaborated by Copernicus. On the other hand, land use refers to the human activities carried out on a certain land cover from a functional dimension (Tor- ricelli, 2015b) and the reference can be represented by the categories of land use proposed by European Environment Agency through Urban Atlas. Land use is a determining factor that influences the ability of ecosystems to provide services (EEA, 2015).

From a combination of the two informative layer, a system of Land Use Functions (LUF) is developed according to the categories proposed by Pérez-Soba et al. (2008), to which the cycles of the activities of the supply chain and the resources that feed these activities refer. As stated by Verburg et al., (2009), more attention should be given to land use as well as to LUF and to the correlations between the two.

LUF can be defined as the "goods and services that the use of land provides to human society, which are of economical, ecological and socio-cultural value and are likely to be affected by policy changes" (ESPON, 2013, p. 12). LUF, representing the social, environmental and economic issues of a territory, are classified by Pérez-Soba et al. (2008) as follows:
Provision of work;
Human health and recreation;
Cultural and aesthetic values; Land-based production;
Residential and non land-based industry and services; 
- Infrastructure;

Provision of abiotic resources;

Support and provision of biotic resources;

Maintenance of ecosystem processes.

Each LUF can be analyzed from an environmental, social or economic perspective according to the wastescape to characterize. LUF consideration allows to complete the pattern definition.

The following step is related to the processes that happen in the territorial system, as the activities of the supply chain that define the territorial processes are contained in the LUF categories. In particular, it is possible to identify two systems:

- The background system, that is related to the activities of extraction, production, distribution and consumption, each of them generating a certain amount of waste;

- The foreground system refers to the WM activities that happen in the Focus Area or Region (Taelman et al., 2017). Collection is a transversal activity, followed by storage, transport and treatment of the collected amount.

These territorial processes determine an effect represented in the form of impacts at micro, meso and macro level (Taelman et al., 2017) as well as the above-mentioned wastescapes.

The next step is the drivers identification; drivers refer to causes of alteration of the territorial functioning and represent factors of change with influence on the environment and also on economy and society. According to Dijst et al. (2018, p. 193), "drivers refer to macro developments which have an impact on needs and constraints experienced at the micro (individual or community) level. We can distinguish various types of drivers: socio-cultural (e.g. values and norms), economic (e.g. growth and decline), political (e.g. power relations and policy aims), demographic (e.g. ageing and population decline), urbanization, climate change and natural resources".
The final step of this chain is the identification of performance indicators (Loiseau et al., 2014), characterized by thresholds for a territorial benchmark. If these thresholds are exceeded, they act on the pattern through degradation processes and they generate the transition from services to disservices. While at the initial life cycle the performance is high and the pattern is in a healthy condition, able to provide goods and services through LUF, as the territorial processes take place, they generate drivers of change and the life cycle tends to run out, until it flows into the wastescapes at the end of the territorial life cycle.

In the following chapters, it will be proposed a methodology to spatially identify a category of wastescapes represented by abandoned industrial buildings.

\section{CASE STUDY}

The case study selected for the experimental application coincides with the Focus Area (FA) chosen for the Italian case study in the Horizon 2020 REPAiR Project (Geldermans et al., 2017), formed by a portion of the Metropolitan Area of Naples (MAN), that includes the following municipalities (Figure 3):

- Acerra;

- Afragola;

Caivano;

Casalnuovo di Napoli;

- Casoria;

- Cardito;

- Cercola;

- Crispano;

- Frattaminore;

- Naples (with the following areas: Poggioreale, Industrial Zone, Ponticelli, San Giovanni a Teduccio, Barra); - Volla.

The boundaries of the Neapolitan case study have been selected in REPAiR Project through a reasoning based on the spatial organization of the area. One of the aspect that

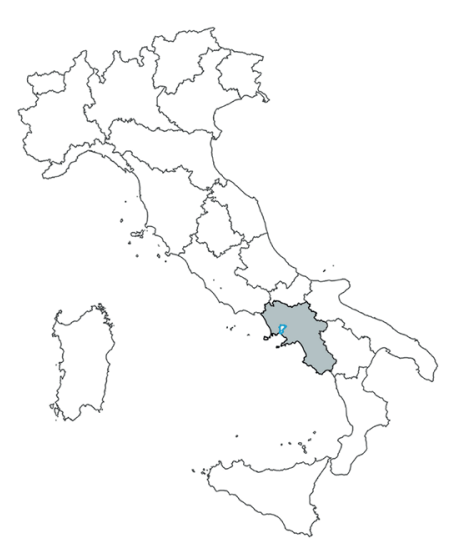

Italy

Campania Region

Focus Area

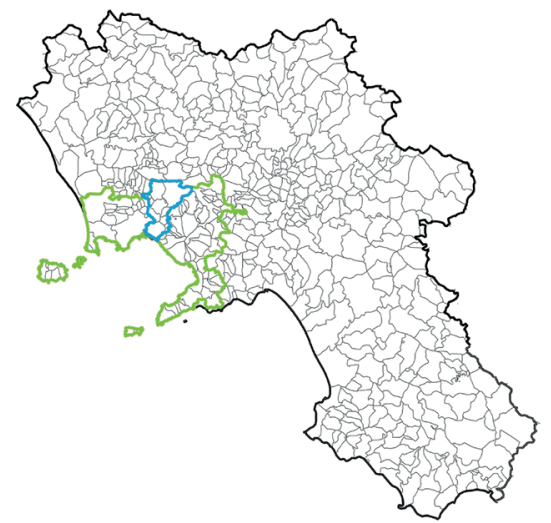

Campania Region

Metropolitan Area of Naples

Focus Area

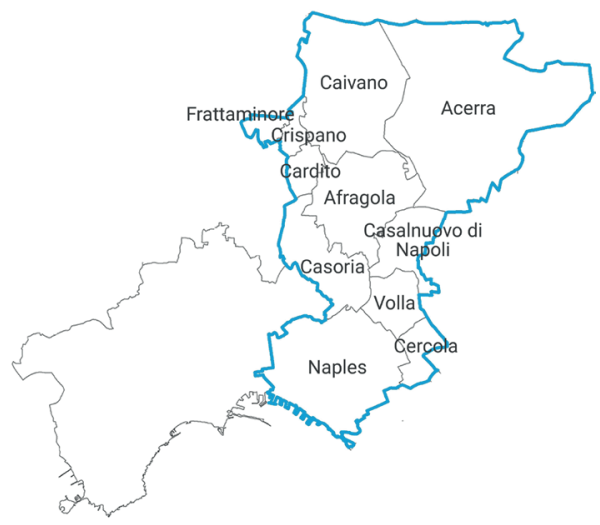

Focus Area with Naples Municipality

Focus Area

FIGURE 3: Focus Area boundaries. 
has been taken into account is the territorial distribution of the transport system together with some ecological aspects. As a matter of fact, the case study is crossed by a plain area and by a network of rectilinear channels, mostly artificial, located in the North-Eastern part of Naples and known as "Regi Lagni", that was worth including.

Metropolitan cities in general are territorial entities of wide area aimed at the care of the strategic development of the metropolitan territory, the promotion and integrated management of services, infrastructures and communication networks and finally the care of institutional relations, including those with European cities and metropolitan areas (law 56/2014, art.1). In addition, metropolitan areas require as well suitable planning instruments because of the presence of environmental conditions that are more critical due to energy consumption and greenhouse gas emissions, generating many negative impacts.

The MAN as a whole can be considered highly affected by territorial aggressions of human matrix (Mazzeo and Russo, 2016) and it is formed by 92 municipalities, representing the third most populated metropolitan area in Italy, with more than 3.5 million inhabitants.

The MAN is also characterized by an unregulated urban development and during the last two decades, the different municipalities have welded together, creating undifferentiated suburbs, with socio-economic and environmental disorder. Moreover, it is marked by an extremely anthropic urban development with a notable population density and the occurrence of both phenomena of density and of dispersion of settlements at the same time (Formato and Russo, 2014), which make the territorial development somewhat chaotic. Furthermore, congestion and urban chaos are the dominant characteristics, especially in the outlying areas. For this reason, the urban conditions of the suburbs of Naples are among the main concerns of the city. In this area, there are numerous environmental and social problems, for which the search for a solution is one of the main challenges that the city has to face (Morelli and Salvati, 2010). Moreover, the MAN has an irregular development due to the lack of an integrated plan of coordination of the entire territory, but a succession of sectorial plans. This led to the presence of a fragmented territory, often caused by the succession of illegal settlements and by a continuous of built up soils, interrupted by poorly connected rural areas.

Facing the specific merit of the selected case study, it is a territory characterized by the combination of valuable elements and at the same time elements characterized by a high degree of fragility together with a considerable concentration of peri-urban areas. The latter are characterized by the symbiotic interaction between rural/natural ecosystems and urban ecosystems (Zhu et al., 2017), habitually seen as residual areas lacking in identity and autonomy and usually located near large urban agglomerations (Gonçalves et al., 2017). As defined in the REPAiR Project, peri-urban areas deal with hybrid portion of territory, sometimes characterized by densely urbanized areas, agricultural land, discontinuous campaigns, as well as abandoned territories, pervaded by degraded ecosystems, with high levels of pollution. In particular, in the South area
(Naples, Casoria, Volla, Cercola, Casalnuovo di Napoli) the main feature is the presence of abandoned land linked to the presence of former refineries and oil depots with a consequent intense level of pollution of soils and aquifers. The East area (Caivano, Acerra, Frattaminore, Crispano, Cardito, Afragola) is characterized by an under-utilization of agricultural land and the presence of huge infrastructural systems with many phenomena of disposal. Anyway, despite the problematic context of the present case study, there is also great potential of development, thanks to the territorial variety, the presence of high quality landscapes and many economic, cultural and environmental resources.

Definitely, metropolitan areas require suitable planning instruments because their environmental conditions are more critical and these instruments could be better applied if supported by useful evaluation methodologies. It is necessary to build a solid knowledge base able to support the decision making phase not only at the metropolitan level but also at different and smaller scales, according to the variety of the territory. The aim is to enhance the capabilities that the territory is already able to offer and to act on the weaknesses in order to create environmental, economic and social win-win solutions.

\subsection{Wasted landscapes: dismissed industrial areas}

According to ISTAT, about $3 \%$ of the entire Italian territory is occupied by abandoned industrial areas. In Italy, there is a specific distinction between "dismissed industrial areas", that are areas in need of processes of redevelopment and "contaminated sites", that require processes of reclamation. According to the Environmental Code, dismissed sites in general can be defined as sites were production activities ceased. Dismissed sites can be:

\section{Contaminated; \\ Potentially contaminated; \\ Non-contaminated.}

In the last decades, because of the economic crisis and the changes in the productive sector (especially in the most advanced countries), there has been a progressive reduction of industrial activities. This process has determined the born of large dismissed areas with the presence of abandoned industrial buildings, very often located in peri-urban areas that are strategic for the urban development. As a consequence, the re-development of these areas constitutes a current problem of considerable interest, characterized by economic, social and environmental repercussions and it represents as well an unavoidable opportunity for activating urban regeneration actions and for the valorization and re-connection of peri-urban areas. For this reason, new operational methods and techniques are required, in compliance with environmental compatibility (Arbizzani and Materazzi, 2012).

It is possible to add that when an industrial activity ceases, it leaves not only a physical vacuum, but it also continues to occupy the territory, polluting it with its residues. Above all, since the mid-1980s, industrial dismissed areas have been recognized as a form of heritage to preserve as a demonstration of the cultural value that it is possible to 
attribute to productive activities and for this reason, it is worth preserving and promoting this form of heritage.

The disused industrial areas are also generally already served by the main infrastructures and are often located near railway plants or important sections of the road network that can determine a good accessibility, therefore the return of these areas to the city can constitute an important occasion for the redesign of the local urban fabric (Aiello, 2012). The recovery of abandoned industrial areas connected to the location of new important urban and productive functions, can be configured as a unitary intervention of metropolitan level, able to define places and relationships related to a large pool of users and able to renew and increase the points of reference in the vast territory (Miano, 2005).

For the case study elaboration, the selected wastescape category is called "settlement and building in crisis" and it is formed by a series of subcategories represented by: vacant/underused, neglected or obsolescent buildings and settlements, urban settlements suffering from fatigue, informal settlements, urban lots in transformation, unauthorized buildings and settlements, confiscated assets. The application is focused on the subcategory "vacant/ underused buildings and settlements", that in REPAiR Project is described as follows (Geldermans et al., 2017, p.17): "vacancy and underusing phenomena can be the direct consequences of the urban decline, due to several factors in the organization of the territory. Economic changes/crisis could also cause abandonment of settlements, or of some parts of them. In this category, abandoned, vacant, underused, dismissed industrial, commercial, military buildings are also included. Examples are: a) brownfields; b) abandoned historic buildings (farms, houses, mills); c) building blocks with high percentages of apartments and/or offices and/or commercial premises not leased; d) agricultural products (such as greenhouses or shelters)".

\subsection{Methodological application: spatial identification of abandoned industrial areas in the Focus Area}

The model of characterization presented in paragraph 2.2.1 is applied in order to characterize and spatially identify the selected wastescape category.

First of all the correspondent land cover and land use that host vacant/underused industrial buildings are represented respectively by artificial land cover, in particular industrial and commercial units and industrial use (known as "industrial, commercial, public, military and private units") (Figures 4-6). Combining land use and land cover, it is possible to select the correspondent LUF, represented by "residential and non land-based industry and services", according to the industrial activity, in particular the activity of production, with reference to the supply chain (Figure 7).

Various typologies of degradation processes can alter the available resources, that in this case are represented by the land that houses the industrial activities and by the building stock itself that is no longer able to perform the economic functions previously carried out. It is not easy to go back to the specific drivers that caused the disposal
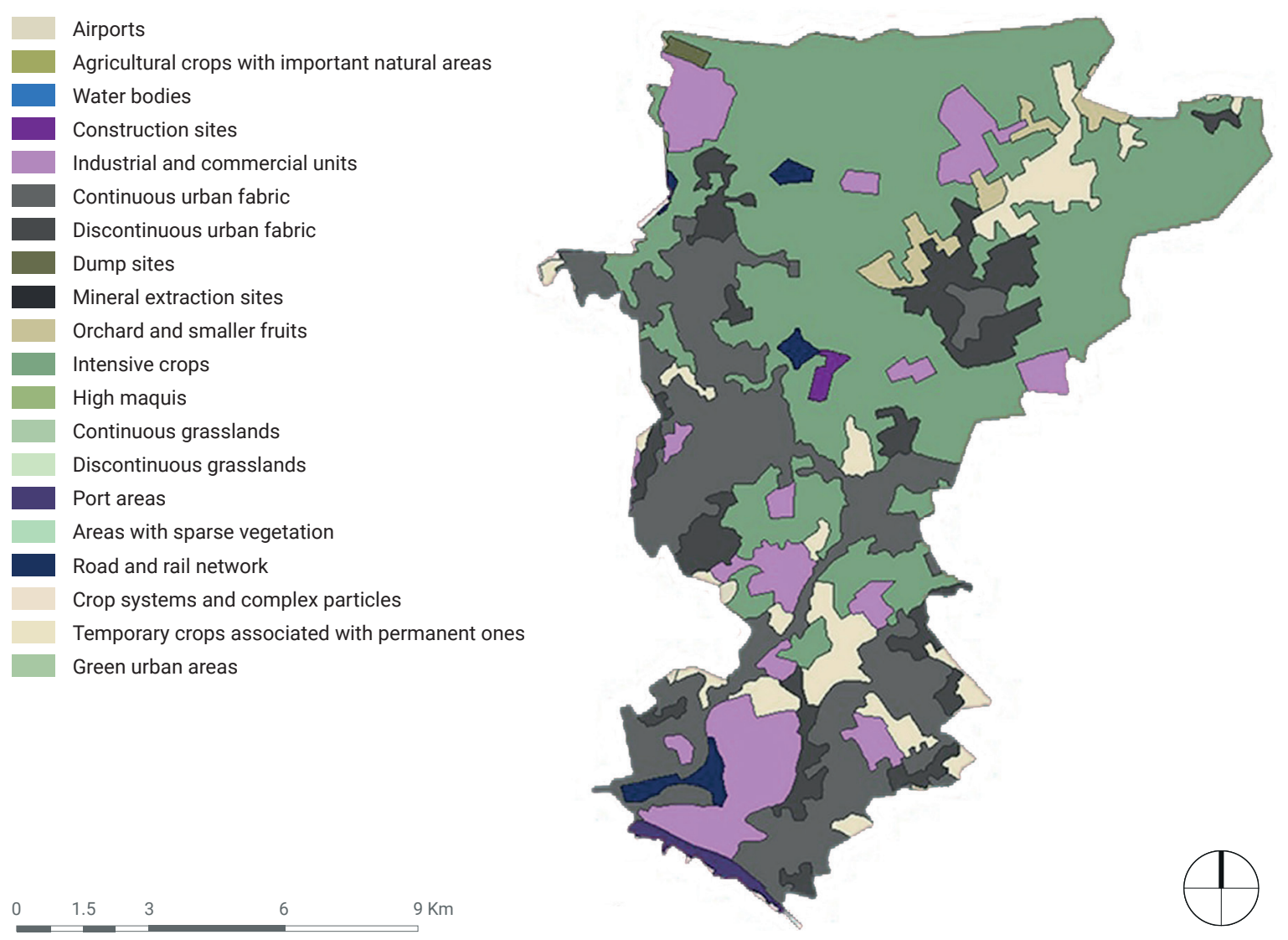

FIGURE 4: Focus Area land cover based on CLC. 
Airports

Arable land (annual crops)

Construction sites

Continuous urban fabric

Discontinuous dense urban fabric

Discontinuous low density urban fabric

Discontinuous medium density urban fabric

Discontinuous very low density urban fabric

Fast transit roads and associated land

Forests

Green urban areas

Herbaceous vegetation associations

Industrial, commercial, public, military and private units

Isolated structures

Land without current use

Mineral extraction and dump sites

Open spaces with little or no vegetation

Other roads and associated land

Pastures

Permanent crops

Port areas

Railways and associated land

Sports and leisure facilities

Water

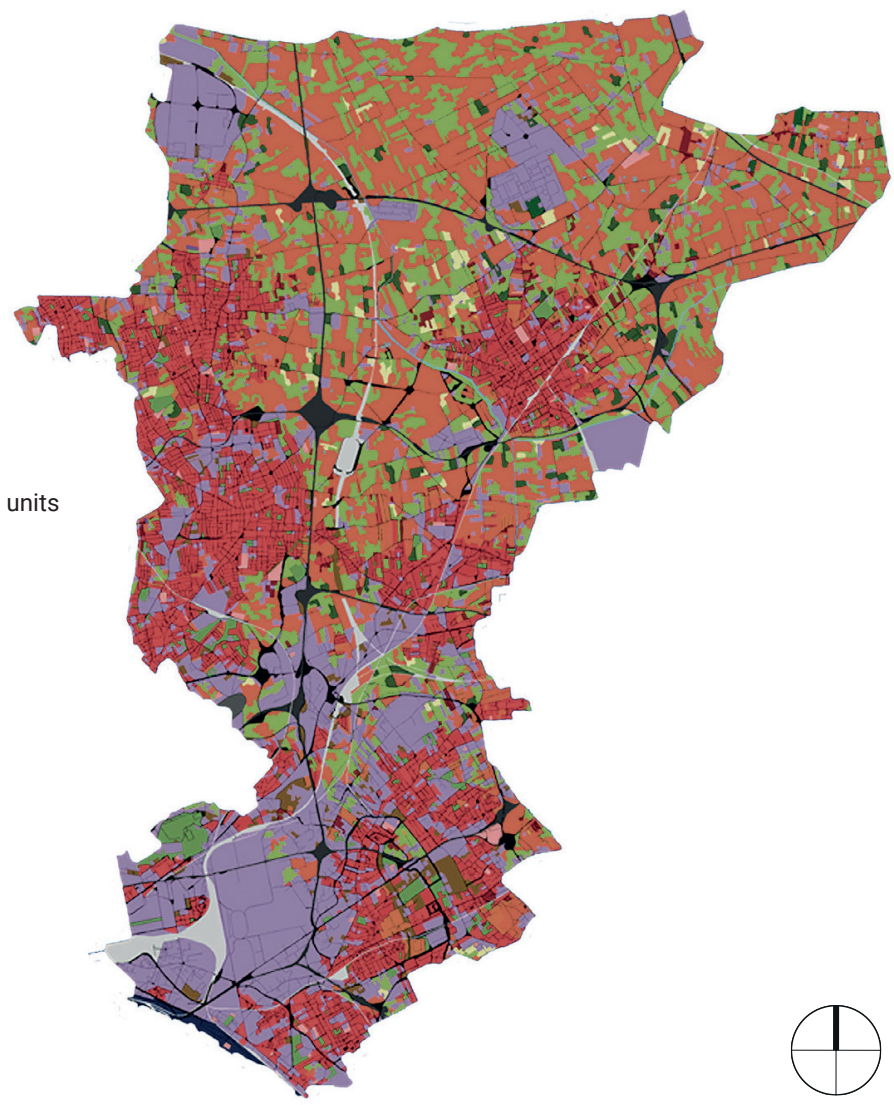

53

6 $9 \mathrm{Km}$

FIGURE 5: Focus Area land use based on Urban Atlas, year 2012.

Industrial and commercial units

Industrial, commercial, public, military and private units

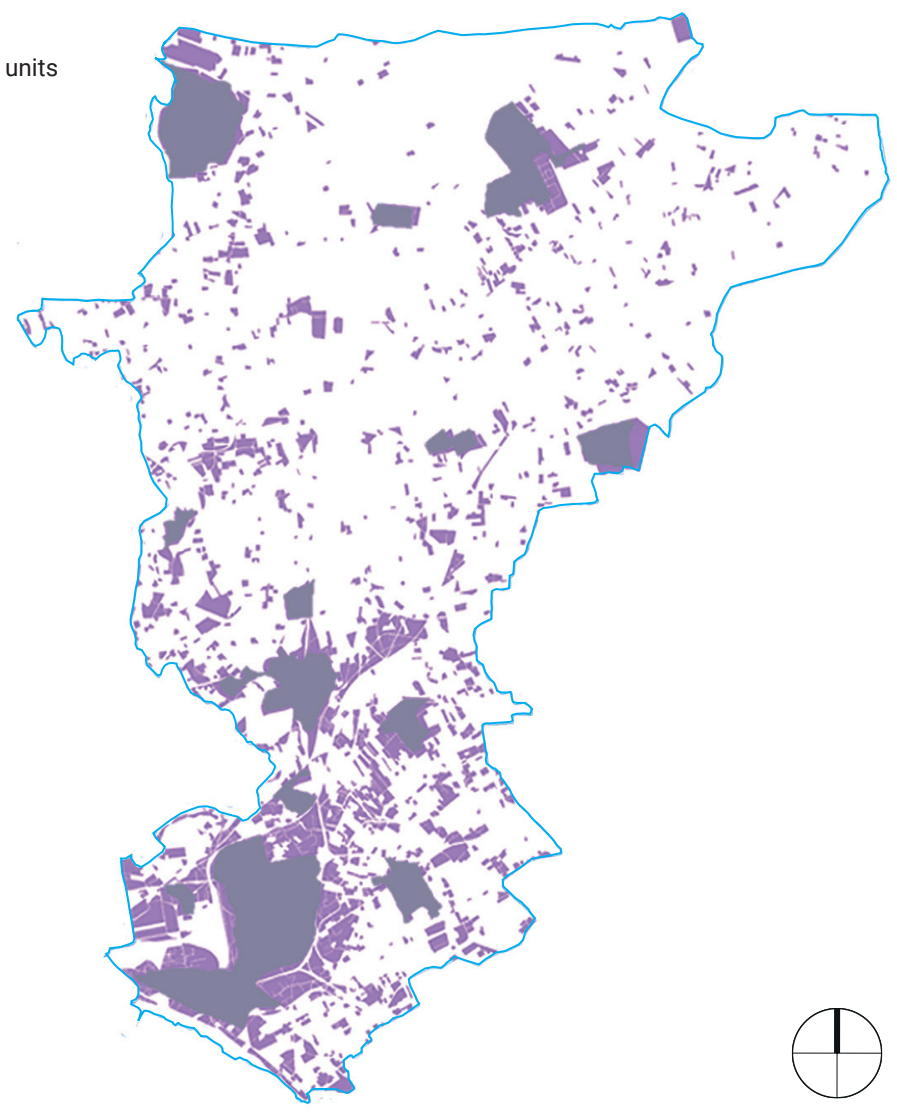

FIGURE 6: Wastescapes characterization model. 


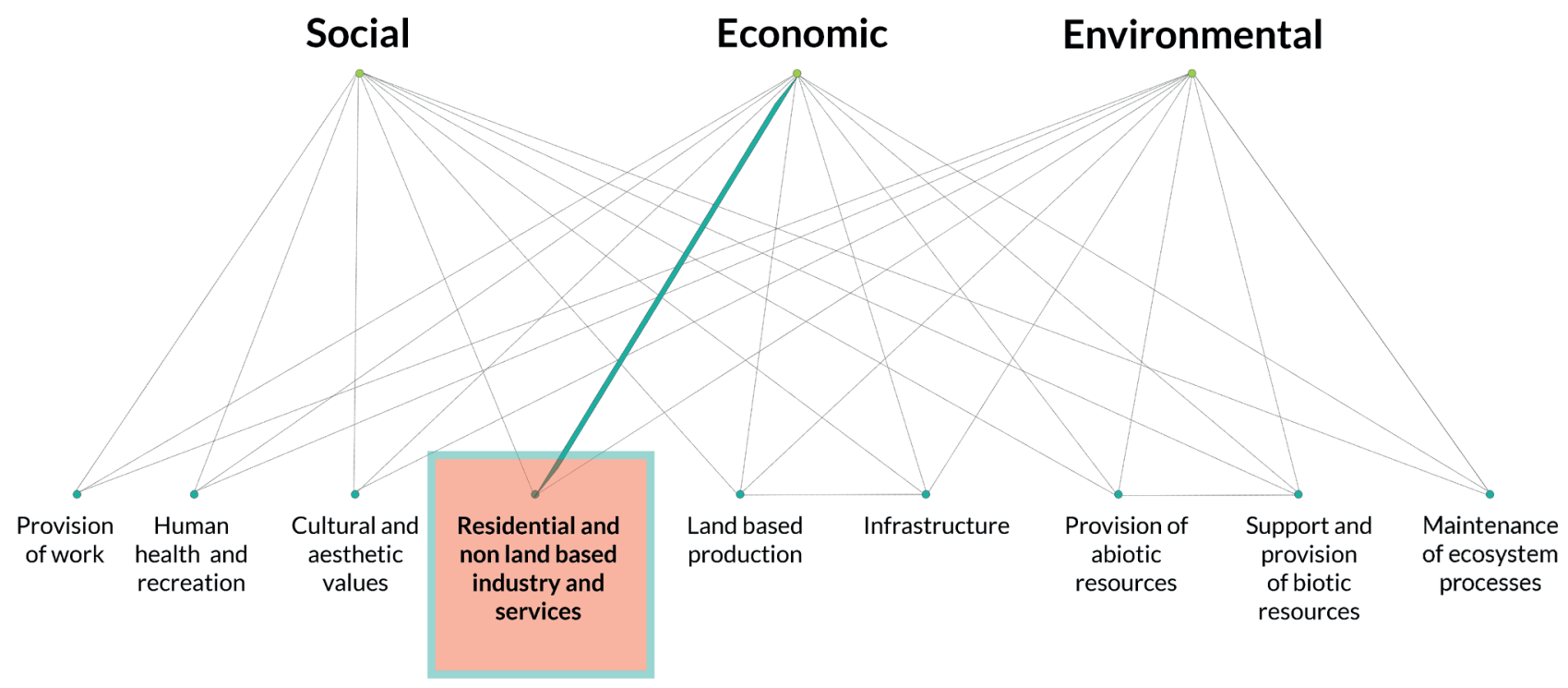

FIGURE 7: LUF identification.

of industrial buildings, but often the closure and the transfer of the plants are due to the contraction of the productive apparatus and the tendency to transfer the productive activities in countries with low labor costs. Therefore, it is possible to assume that drivers are represented especially by economic factors.

The final step of this methodology is represented by the selection of a performance indicator, that in this case is represented by the number of employees. Where the number of employees is equal to 0 (assumed as the previously described threshold), it can be a potential abandoned industrial building, passing from the industrial productive service to the disservice of abandonment. The data considered in this phase have as a source the industry and services census carried out by ISTAT, and indicate for each census section two relevant information for the purposes of the present survey:

\section{- Number of local units;}

- Number of employees.

These data were subsequently spatially coupled and represented through Geographic Information System (GIS). The use of reference maps is vey significant for the visualization of those elements of the decision-making problem that are characterized by a spatial dimension and has proved to be very useful in various occasions (De Toro et al., 2016; De Toro and lodice, 2016; De Toro and Iodice, 2018).

In order to complete the survey and get to the selection of the investigated wastescape, it was necessary to integrate aerial views through the use of Google Maps, making a first selection of all the areas potentially useful for the analysis. To this, it was added a selection criterion that allowed to make a further reduction of the sections, excluding those that meet the following requirements:

\footnotetext{
Sections containing Roma settlements;

Sections containing plants;

Sections containing greenhouses;
}

\section{Sections containing already demolished buildings.}

Consequently, the sections containing built structures in terms of large abandoned spaces, with abandoned industrial buildings characterized by lack of activity, or where there are often perimeter control activities have been examined.

\section{RESULTS AND DISCUSSION}

The first result of the described methodology is represented in Figure 8. As it is possible to observe, the census sections represented in white are those that contain a number of employees between 0 and 5 . Some, especially those of larger dimensions located in the northern part of the FA, are constituted by agricultural fields. The final result is represented in Figure 9, where, the wastescapes "vacant/ underused, industrial buildings and settlements" can be spatially identified

For the application, by way of example, the attention has been focused on one single wastescape that belongs to this category. The selected wastescape is the former industrial plant known as "Rhodiatoce", located in the Municipality of Casoria (Figure 9).

Casoria (Figure 10) located in the north-eastern suburban part of the Neapolitan area, is characterized by the presence of a series of dismissed areas that determine the existence of abandoned portion of territory and large urban voids without function that delineate a specific landscape, configuring itself as a real environmental issue.

Because of the crisis of urban production facilities, Casoria is represented by an industrial scenario in transition, with many abandoned factories, as skeletons of monuments, as a fixed and resistant scene, in a territory of transformations. One of the main problems to be addressed in view of a possible recovery of these areas is represented by the presence of polluted soils, which determine the need to carry out extensive reclamation operations before any type of intervention. 

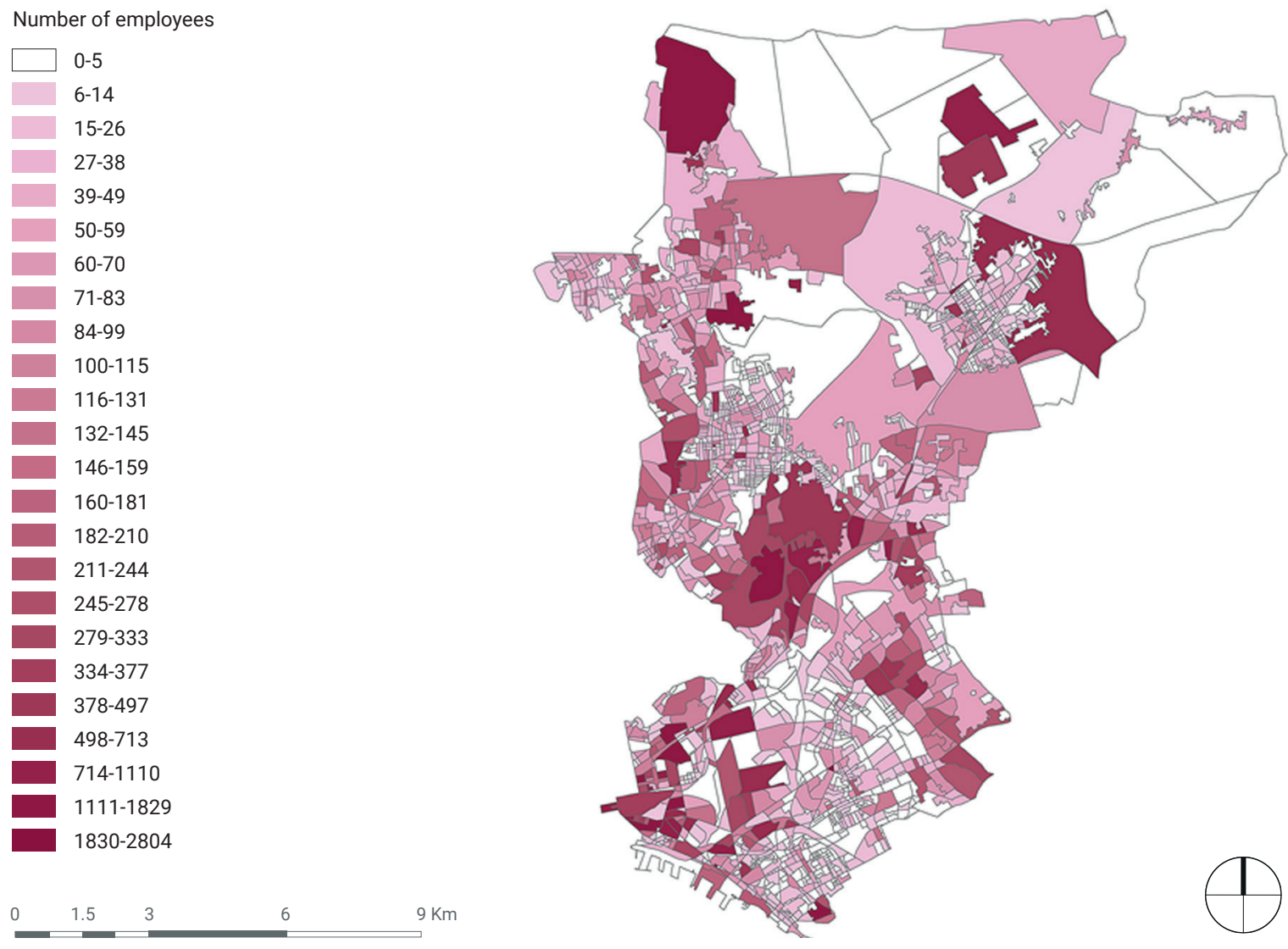

FIGURE 8: Preliminary results.

Vacant/underused industrial buildings Rhodiatoce

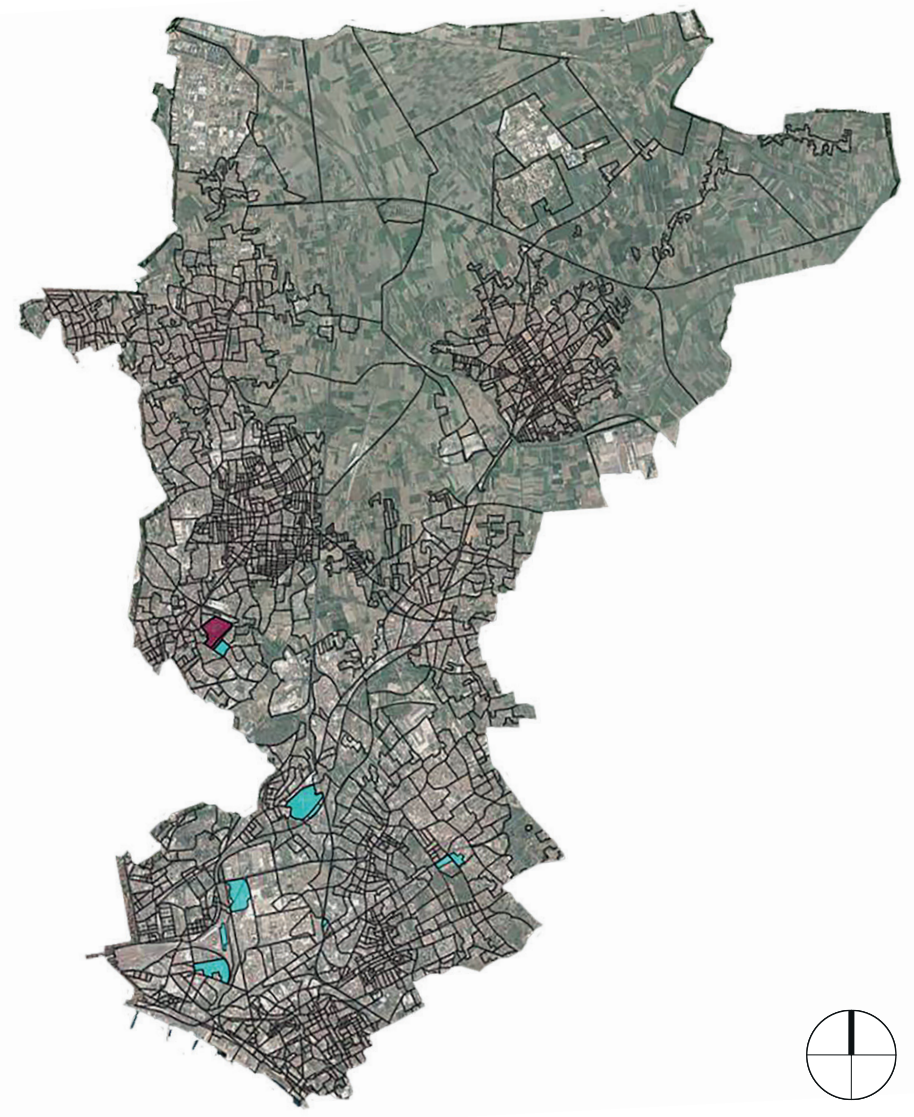

$\begin{array}{lll}0 & 1.5 \quad 3\end{array}$ $9 \mathrm{Km}$

FIGURE 9: Vacant/underused, industrial buildings and settlements with focus on Rhodiatoce industrial plant. 


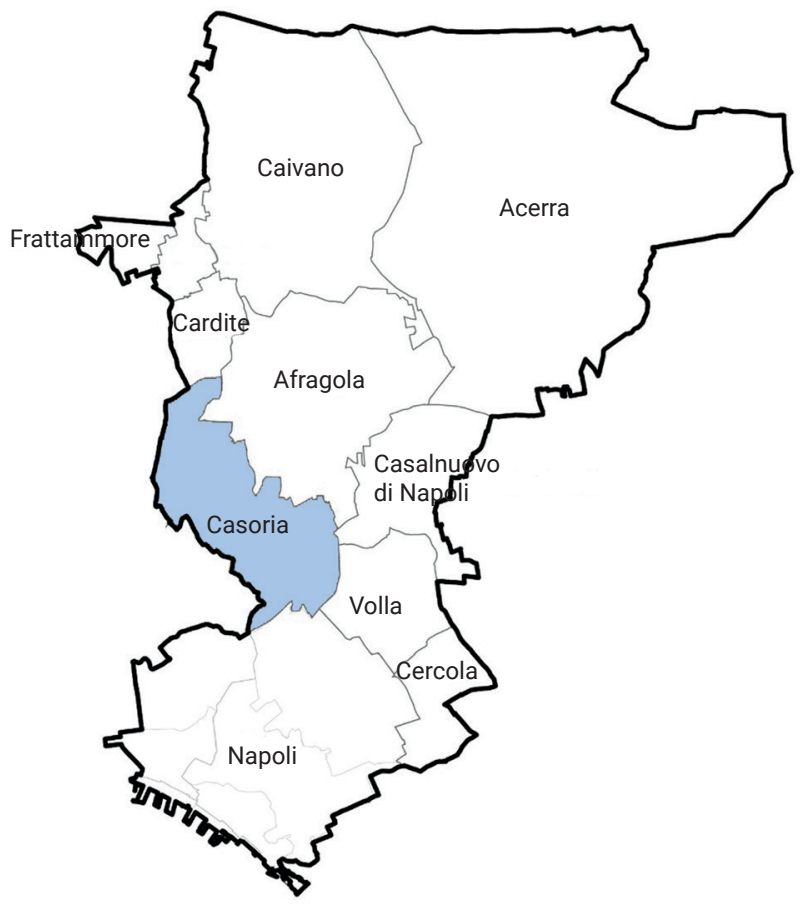

FIGURE 10: Municipality of Casoria.

This industrial landscape has developed and at the same time died in an urban life cycle of around 30 years (Miano, 2005).

The redevelopment of the abandoned industrial areas can be seen in the context of a territorial reorganization, creating the possibility of establishing links between apparently autonomous elements of the urban fabric (Miano, 2005).

Among the five disused industrial plants that characterize the territory of Casoria, there is the Rhodiatoce industrial plant for nylon production, that rises in 1928 and one of its branches was born in 1953; its organization and distribution is accurately described by Miano (2005).

\subsection{The life cycle of a building: how to manage Con- struction and Demolition Waste}

Having previously specified how the territory is characterized by its own life cycle that determines the formation of residual spaces, it is necessary to underline that also the built heritage, in a multi-scale perspective, is endowed with its own life cycle.

The life cycle of a building is based on the analysis of the practices that affect the whole path of life that a building undergoes in the course of some years. The life of a building begins with the design phase, in which the costs and times are the items that most influence the result of the final project. In the next phase, the construction phase, the life cycle of materials, the times, the costs and the building site take on a particular relevance. After the construction, begins the period of use of the artefact in which different functions can be carried out with different subjects who perform maintenance works of the building. A possible next phase is that of abandoning the building.
Some possible scenarios arise subsequently: it is possible a recovery of the building with the part of the disassembly in which the existing conditions are evaluated. It is also possible a complete demolition of the artefact, without a new construction, determining the necessity of the disposal of waste or also its recovery. Finally, the last alternative is the demolition of the building but a subsequent construction of a new building (Baiocco et al., 2017).

As far as the demolition phase is concerned, there are two possible alternative scenarios (Figure 11):

- The first concerns the total demolition of the building, without recovering the waste materials and the construction of a total new building;

- The second alternative is based on the demolition of the existing building and the construction of a new building by reusing part of the demolition materials.

The demolition phase and the way it is carried out depends strictly on the constructive process, underlining the necessity to consider the entire life cycle.

In the demolition phase, it is possible to take two opposite paths:

- The firs concerns the disposal of the materials without any opportunity of recovery;

- The second provides the possible recycling of Construction and Demolition Waste (CDW) and the disposal of the material that it is not possible to recycle.

As a matter of fact, the disposal phase is very relevant and it is necessary to support this phase by accurate economic and environmental evaluation procedures (Baiocco et al., 2017). Furthermore, the application of sustainable development principles can influence and improve the sustainability of urban ecosystems and among this principles there is that of Waste Management (WM) (Dizdaroglu, 2015).

CDW belongs to the category of Special Waste, which in turn is divided into hazardous and non-hazardous one. The CDW flow is produced during the life cycle of a project, that can be summarized in three main phases (Wu et al., 2014):

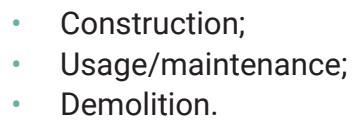

4.1.1 Life Cycle Assessment as a tool to support the regeneration of abandoned industrial areas: CDW quantification methods

At this point, it is necessary to specify that it is important to collect reliable information on the expected quantities of CDW in order to facilitate the establishment of policies and alternative possible solutions (Ding and Xiao, 2014), also using environmental assessment methods able to improve the decision making phase. One of the most useful tool is represented by Life Cycle Assessment (LCA), that can provide quantitative information, able to facilitate the selection of sustainable choices (Helling, 2017).

Usually LCA takes origin from the production of raw materials until their disposal, i.e. "from cradle to grave", 


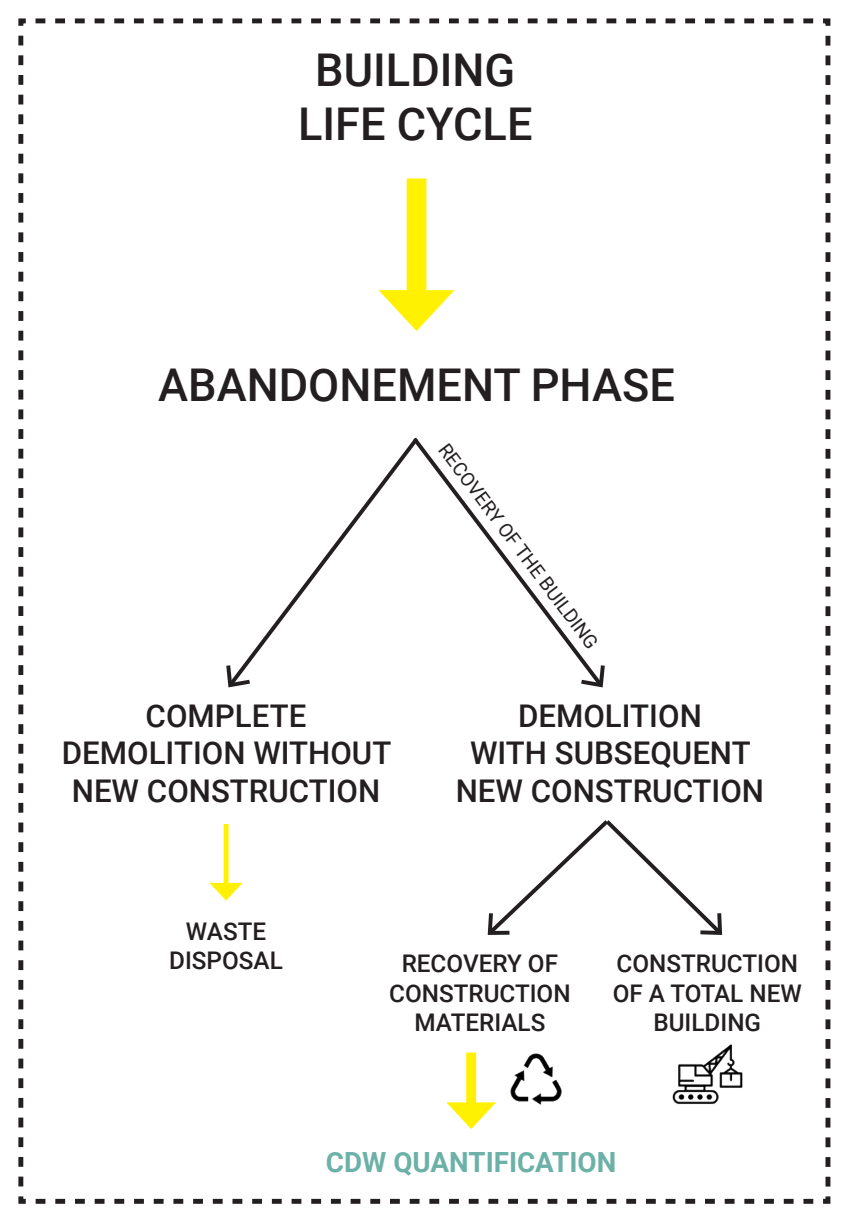

FIGURE 11: Building Life Cycle.

but could be an useful instrument also for specific phases of the life cycle, such as that of WM. The latter comprises everything that happens when the product becomes waste, in order to evaluate the impacts of its disposal (Turconi et al., 2011; Brogaard and Christensen, 2016; Taelman et al., 2019).

Supposing a reuse and requalification of Rhodiatoce industrial plant following the architecture project described in Miano (2005), it is necessary to bear in mind that a clear tendency to rise for the next years for retrofitting and demolition activities is shown and since they have proven to generate more waste than construction activity (Coelho and De Brito, 2011), it is necessary to identify a suitable quantization model and to monitor the environmental impacts.

As stated by Martínez Lage et al. (2010) and Ding and Xiao (2014), CDW is the sum of Construction and Demolition Flow as well as the waste produced by retrofitting or renovation activities.

CDW quantification represents a fundamental prerequisite in order to implement a successful WM. Wu et al. (2014) propose an analytical review of the existing quantification methods, introducing a first distinction between quantification at two different levels:

\footnotetext{
At regional level, with the aim of quantifying CDW of all projects in a particular region;
}

- At project level, that has the aim of forecasting CDW quantities in a single project.

Still Wu et al. (2014) identify six major categories of quantification methodologies:

Site Visit method (SV), in which it is possible to adopt both direct measurement, through which the waste produced is measured on site and indirect measurements, such as truck load records and on-site interviews as well. - Generation Rate Calculation (GRC) method, that is based on the waste generation rate for a particular activity unit (for example $\mathrm{Kg} / \mathrm{m}^{2}$ ) and the amount of total units. This category of methods can comprise per capita multiplier, financial value extrapolation and area-based calculation. The latter can be estimated by multiplying the generation rate and the total area.

- Lifetime Analysis (LA) method that is based on material mass balance and on the principle according to which the amount of demolition waste must equal the mass of the construction. This methodology is divided in building lifetime analysis and material lifetime analysis.

- Classification System Accumulation (CSA) method, that is based on a platform for quantifying different specified materials.

- Variables Modelling (VM) method is based on the principle according to which CDW quantification and generation depend on a series of variables such as economic indicators, construction areas, etc. Very interesting can be the quantification framework based on an "Activity Based Waste Generation" (Wimalasena et al., 2010), according to which the total CDW quantity can derive from the sum of the waste quantities produced in each construction activity.

- Other methodologies, such as method based on chemical characteristics or method based on fix percentages of the purchased materials.

These methodologies can be adopted either individually or in combination, depending on the needs.

As far as site visit is concerned, this method could be the most precise but it is time consuming and costly and it could be characterized by significant barriers (Franklin Associates, 1998).

The first factor to determine for the application of the calculation model is represented by waste characterization. Secondly, the main factor for the estimation of CDW is represented by the Waste Generation Rate (WGR), that depends on the quantity of material developed from different sources (Ghosh et al., 2016). Different quantification formulas have been proposed in the literature; for example Kofoworola and Gheewala (2009) suggest to apply for construction waste the quantification model based on the following formula (1):

$Q x=A * G a v * P x$

whereas Qx represent the quantity (tons), $\mathrm{A}$ is the area of activity, Gav is the waste generation rate and $\mathrm{Px}$ is the percentage of waste material. Martínez Lage et al. (2010) propose a quantification model that estimates a quantity of $80 \mathrm{~kg} / \mathrm{m}^{2}$ of CDW for new construction work, $1350 \mathrm{~kg} /$ 
$\mathrm{m}^{2}$ of waste for demolition work and finally $90 \mathrm{Kg} / \mathrm{m}^{2}$ for renovation work.

According to the data availability, for the present application it is considered appropriate to choose the method indicated by Wu et al. (2014) as "area based calculation" linked to the "generation rate calculation" category.

Therefore adopting the formula proposed by Kooworola and Gheewala, (2009) (1) and the estimations of Martínez Lage et al. (2010) ${ }^{3}$, it is expected that (2-3-4):

Construction Waste $=A n c * 80 \mathrm{~kg} / \mathrm{m}^{2}=25955^{4} \mathrm{~m}^{2} * 80 \mathrm{~kg} /$ $\mathrm{m}^{2}=2.076 .400 \mathrm{~kg}$

where Anc is the total area of new construction based on the project of renovation described in Miano (2005).

Renovation Waste $=A r c * 90 \mathrm{~kg} / \mathrm{m}^{2}=1416 \mathrm{~m}^{2} * 90 \mathrm{~kg} / \mathrm{m}^{2}$ $=128 \mathrm{Kg}$ of total $\mathrm{RW}$

where Arc is the total area of the renovated building, as established by Miano (2005).

Demolition Waste $=$ Adc * $1350 \mathrm{~kg} / \mathrm{m}^{2}=46000 \mathrm{~m}^{2} * 1350$ $\mathrm{kg} / \mathrm{m}^{2}=62.100 .000 \mathrm{~kg}$

where Adc = is the total area of the demolished building always according to the demolition proposed by Miano (2005).

Therefore the total CDW flow is:

$C W+R W+D V=(2.076 .400+128+62.100 .000) K g=a b o u t$ 62.102.204 Kg.

At this point it is necessary to specify that these are forecast estimates based on broad indicators and which naturally determine plausible but not effective results. To this end, it would be necessary to use the "direct measurement" method during the actual construction and demolition phases linked to the building transformation processes envisaged for the future.

Once quantified the CDW that would arise from a renovation project of Rhodiatoce factory, it could be possible to run a LCA model to assess the environmental impacts linked to the treatment of CDW, in order to identify some sustainable guidelines aimed at reducing environmental impacts.

TABLE 1: Material fractions for Rhodiatoce industrial plant: a hypothesis.

\begin{tabular}{|c|c|}
\hline Material Fractions & $\%$ \\
\hline Bituminous mixture & 0.5 \\
\hline Clear Glass & 1.5 \\
\hline Mixed CDW & 45 \\
\hline Insulation materials & 1 \\
\hline Ferrous components & 5 \\
\hline Concrete & 35 \\
\hline Ceramics & 0.5 \\
\hline Wood & 1.35 \\
\hline Gypsum & 0.15 \\
\hline Soil & 10 \\
\hline
\end{tabular}

As regards the quantitative information related to the individual flows, REPAiR Projects performs a LCA for the CDW produced in the Focus Area and has officially received from the Campania regional agency for environmental protection (in Italian "Agenzia Regionale per la Protezione Ambientale in Campania" - ARPAC) data related to CDW flow according to the year 2015 (Tonini et al., 2019). For the present application, the percentage considered for the flow produced in the Focus Area is basically maintained and it is considered representative of an average CDW flow. Anyway, some adjustments are necessary according to the specificities of the building.

Therefore, on the basis of these two information, namely on the one hand the flow produced in the Focus Area and in Campania Region, described in Tonini et al. (2019) and the temporal and constructive characteristics of the building that create the necessity to eliminate some fractions and to make a general calibration, a possible hypothesis of the CDW fractions coming from Rhodiatoce renovation could be the ones represented in Table $1^{5}$.

\section{CONCLUSIONS: WHAT'S NEXT?}

Urban ecosystems are characterized by complex social-ecological interactions where sustainable choices made in one place can create social, economic or environmental problems elsewhere (McPhearson et al., 2016). Urban ecosystems, in their complexity, like living organisms, have also their own metabolism, whose functioning is linked to the presence of input and output streams. Hence the concept of UM has been introduced and described together with the concept of territorial life cycle. This is because the territory, like living organisms, is not only endowed with its own metabolism but is also marked by the succession of life cycles that are shaped by metabolic flows. The portions of territory that are at the end of their life cycle, configure themselves as territorial waste, and a spatial methodology for their identification has been proposed. A multi-scale approach is adopted, as cross-city comparison at multiple scales is a key quality to understand and analyze the complexity of social-ecological interactions (McPhearson et al., 2016) (Figures 12-13).

Focusing on one single category among the wastescapes proposed in the Horizon 2020 Project REPAiR, the attention has been focused on the abandoned industrial areas. Here, the LCA could be a valid instrument to support the decision-making phase of possible renovation actions, providing useful information about the environmental impacts connected to the management of the metabolic flow represented by Construction and Demolition Waste.

This procedure serves also to demonstrate how the LCA tool could prove to be useful in supporting the regeneration of the territory, and in this case to support the demolition and reconstruction of the abandoned buildings, suggesting to the decision makers good practices of demolition and reconstruction, such as that of selective demolition. As a matter of fact, at the scale of city and urban region, LCA is a field of application that has not yet been properly explored (Albertì et al., 2017) (Figure 14). 


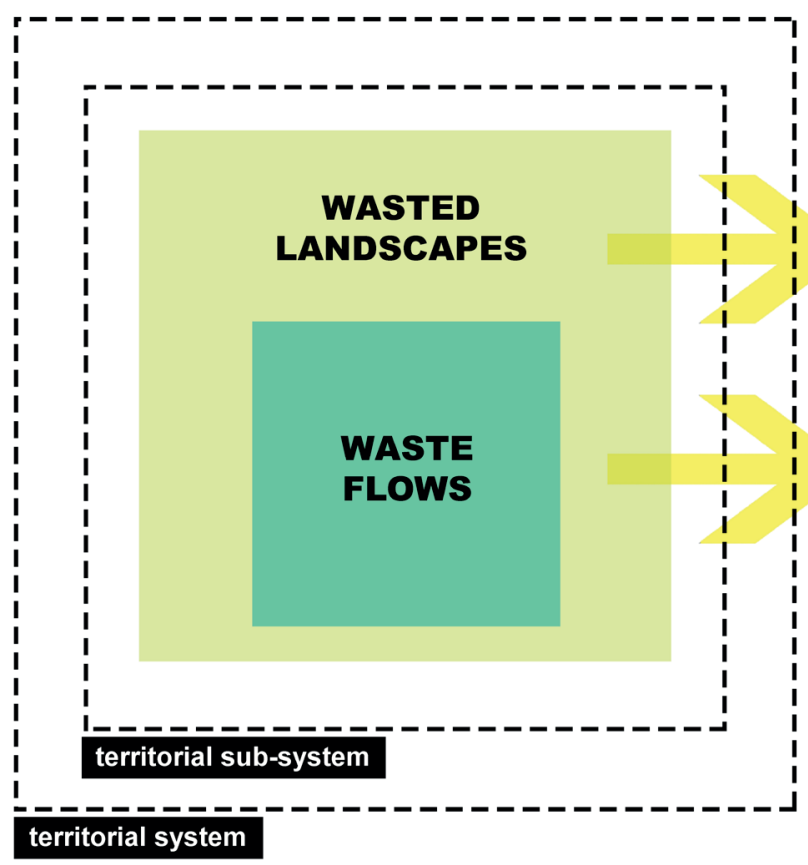

\section{Abandoned industrial areas}

\section{Construction and Demolition Waste}

FIGURE 12: From wasted landscapes to waste flows.

This example also shows that the same procedure could be repeated in the same territory or even in different territories to identify and support the redevelopment of the abandoned building heritage.

Definitely, the present paper proposed a first possible association of LCA as a tool to support the regeneration of the territory, but it is also open to future advances. For example, it is possible to take into account all the other wasted landscapes, in order to calculate the total amount of CDW that would come out of the regeneration of abandoned industrial buildings in the Focus Area. The real challenge would also be the reuse of the materials of abandoned artifacts, using LCA to asses the economic

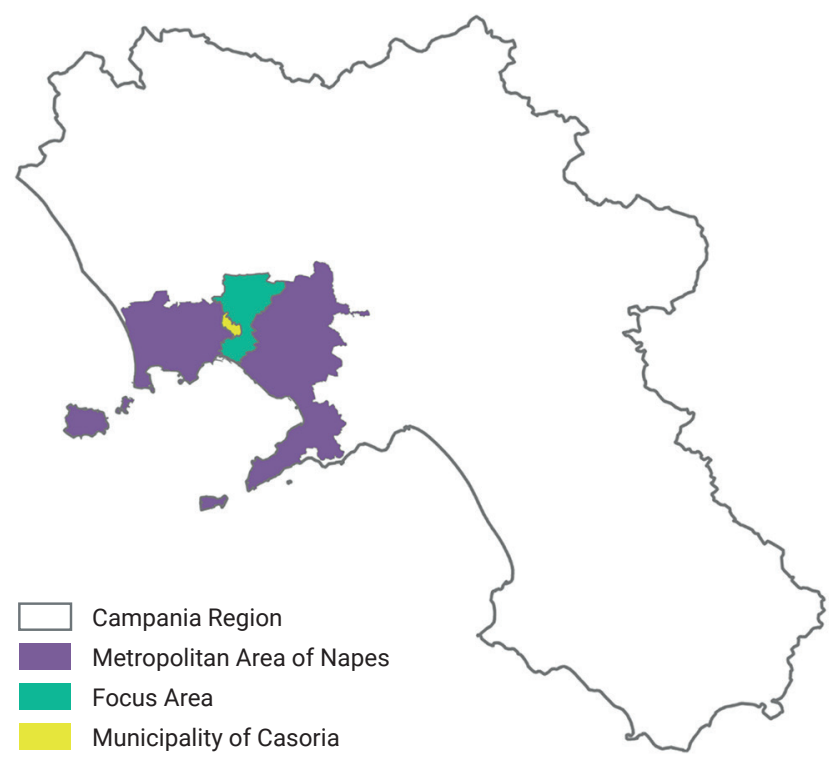

FIGURE 13: Multi-scalarity. and environmental costs of this recovery, that in general could be energy-intensive and thus very demanding for the environment. In this perspective, a very useful approach focusing on the territorial aspects of LCA is that represented by the "Territorial LCA" (Loiseau et al., 2012; Loiseau et al., 2013; Louseau et al., 2014; Loiseau et al., 2018) that focuses on the impacts linked to the territorial activities, comprising also that of WM.

Secondly, it is also possible to focus on other activities that take place on the territory or on other types of metabolic flows, to support the regeneration of other typologies of wastescapes. The real step forward, however, would consist in the geographical mapping of impacts (Gargari, 2015), which is linked to the distribution of pollutants in the air. Indeed, the combination of the results of an LCA evaluation with models of territorial mapping of emissions is an innovative development line in relation to the issue of spatialization of environmental impact indicators.

Urban Region
City
District
Neighborhood
Block
Building
House
Constructive system
Construction product

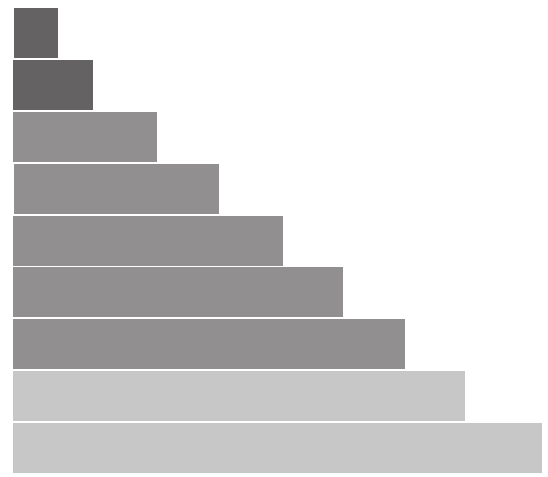

FIGURE 14: Hierarchy of the built environment, adapted from Albertì et al., (2017). 


\section{AKNOWLEDGEMENTS}

The authors would like to thank the whole REPAiR Team, and especially the Research Team of the Department of Architecture, University of Naples Federico II, in Italy, and the Team at Delft University of Technology, in the Netherlands.

This research has been carried out within the framework of the European Horizon 2020 funded research REPAiR: REsource Management in Peri-urban AReas: Going Beyond Urban Metabolism. This project has received funding from the European Union's Horizon 2020 research and innovation programme under grant agreement no. 688920 . This article reflects only the authors' view. The Commission is not responsible for any use that may be made of the information it contains.

\section{AUTHORS CONTRIBUTION}

Conceptualization: Silvia lodice and Pasquale De Toro; methodology and data curation: Silvia lodice and Pasquale De Toro; formal analyses: Silvia lodice; writing, review and editing, Silvia lodice. All authors have read and agree to the published version of the manuscript.

\section{REFERENCES}

Aiello, F. (2012). II recupero delle aree industriali dismesse. http://www. scienzainrete.it/contenuto/articolo/recupero-delle-aree-industriali-dismesse.

Albertí, J., Balaguera, A., Brodhag, C., \& Fullana-i-Palmer, P. (2017). Towards life cycle sustainability assessment of cities. A review of background knowledge. Sci. 609, 1049-1063. https://doi. org/10.1016/j.scitotenv.2017.07.179.

Alberti, M., \& Susskind, L. (1996). Managing Urban Sustainability: An Introduction to the Special Issue. Environ. Impact Assess. 16(4).

Amenta, L., \& Attademo, A. (2016). Circular wastescapes. Waste as a resource for periurban landscapes planning. CRIOS, 12, 79-88. https://doi.org/10.3280/CRIOS2016-012008.

Amenta, L., \& van Timmeren, A. (2018). Beyond Wastescapes: Towards Circular Landscapes. Addressing the Spatial Dimension of Circularity through the Regeneration of Wastescapes. Sustainability, 10(12), 4740. https://doi.org/10.3390/su10124740.

Arbizzani, E., \& Materazzi, G. (2012). La riqualificazione delle aree industriali dismesse. Considerazioni di metodo. Hortus, 62, 1-8.

Aymonino, A., Berta, M., Bocchi, R., Cacciaguerra, G., Carta, M., Ciorra, P., Crotti, M., De Rossi, A., Garofalo, F., Gasparrini, C., Gioffrè, V., Ricci, M., Secchi, R., \& Valente, I. (2013). In S. Marini \& V. Santangelo (Eds.). Nuovi cicli di vita per architetture e infrastrutture della città e del paesaggio. Aracne.

Baiocco, R. (2017). Prima parte: La funzione anticiclica degli usi temporanei. In R. Baiocco, L. Silvestrin, \& D. Tecchhio (Eds.), Money Urbanism. Progetto urbano e cicli di produzione della città. Università IUAV di Venezia, 9-29.

Beloin-Saint-Pierre, D., Rugani, B., Lasvaux, S., Mailhac, A., Popovici, E., Sibiude, G., Benetto, E., \& Schiopu, N. (2017). A review of urban metabolism studies to identify key methodological choices for future harmonization and implementation. J. Clean. Prod. 163, S223S240. https://doi.org/10.1016/j.jclepro.2016.09.014.

Berger, A. (2006). Drosscape in the landscape. In C. Waldheim (Ed.), The Landscape Urbanism Reader. Princeton University Press, 197-217.

Berger, A. (2007). Drosscape: Wasting Land in Urban America. Princeton Architectural Press Hachette Book Group.

Brogaard, L. K., \& Christensen, T. H. (2016). Life cycle assessment of capital goods in waste management systems. J. Waste Manag. 56, 561-574. https://doi.org/10.1016/j.wasman.2016.07.037.

Broto, V. C., Allen, A., \& Rapoport, E. (2012). Interdisciplinary Perspectives on Urban Metabolism: Interdisciplinary Perspectives on Urban Metabolism. J. Ind. Ecol. 16(6), 851-861. https://doi. org/10.1111/j.1530-9290.2012.00556.x.

Brown, I. T. (2017). Managing Cities as Urban Ecosystems: Fundamentals and a Framework for Los Angeles, California. CATE 10(2), $1-30$.
Carta (2015), Planning in the Re-cycle age. In S. Marini \& V. Santangelo (Eds.). Nuovi cicli di vita per architetture e infrastrutture della città e del paesaggio. Aracne edtrice, Roma, Italy, 59-64.

Carta, M. (2016). Cityforming Protocol: Strategie incrementali e adattive. In D. Ronsivalle \& B. Lino (Eds.), Re-cyclical Urbanism. Visioni, paradigmi e progetto per la metamorfosi circolare. Listlab.

Carta, M., Lino, B., Ronsivalle, D., \& Carta, M. (2016). Re_cycling urbanism: Visioni, paradigmi e progetti per la metamorfosi circolare. List, Babel.

Chatzinikolaou, P., Viaggi, D., \& Raggi, M. (2018). Review of Multicriteria Methodologies and Tools for the Evaluation of the Provision of Ecosystem Services. In J. Berbel, T. Bournaris, B. Manos, N. Matsatsinis, \& D. Viaggi (Eds.), Multicriteria Analysis in Agriculture. Springer International Publishing, 43-68. https://doi. org/10.1007/978-3-319-76929-5_2.

Coelho, A., \& de Brito, J. (2011). Generation of construction and demolition waste in Portugal. Waste Manag. Res. 29(7), 739-750. https://doi.org/10.1177/0734242X11402253.

Collins, J., Borer, E., Fagan, W., Grimm, N., Hope, D., Kinzig, A., \& Wu, J. (2000). A New Urban Ecology. American Scientist, 88(5), 416. https://doi.org/10.1511/2000.5.416

De Toro, P., Gasparrini, C., \& lodice, S. (2016). Pianificazione urbanistica, paesaggio e valutazione. Una proposta per il Piano Urbanistico Operativo di Cava De' Tirreni. Agribusiness Paesaggio \& Ambiente, XIX, n.2, 137-144.

De Toro, P., \& lodice, S. (2018). Ecosystem Health Assessment in urban contexts: A proposal for the Metropolitan Area of Naples (Italy). Aestimum 72, 39-59. https://doi.org/10.13128/Aestimum-23968.

De Toro, P., \& lodice, S. (2016). Evaluation in Urban Planning: A multi-criteria approach for the choice of alternative Operational Plans in Cava De' Tirreni. Aestimum 69, 93-112. https://doi.org/10.13128/ Aestimum-20450.

Di Gregorio, A. (2005). Land cover classification system: Classification concepts and user manual: LCCS (Software version 2). Food and Agriculture Organization of the United Nations (FAO).

Dijst, M. (2013). Space-Time Integration in a Dynamic Urbanizing World: Current Status and Future Prospects in Geography and GIScience: Space-Time Integration in Geography and GIScience. AAnn. Am. Assoc. Geogr. 103(5), 1058-1061. https://doi.org/10.1 080/00045608.2013.792171.

Dijst, M., Worrell, E., Böcker, L., Brunner, P., Davoudi, S., Geertman, S., Harmsen, R., Helbich, M., Holtslag, A. A. M., Kwan, M.-P., Lenz, B., Lyons, G., Mokhtarian, P. L., Newman, P., Perrels, A., Ribeiro, A. P., Rosales Carreón, J., Thomson, G., Urge-Vorsatz, D., \& Zeyringer, M. (2018). Exploring urban metabolism-Towards an interdisciplinary perspective. RESOUR CONSERV RECY 132, 190-203. https://doi. org/10.1016/j.resconrec.2017.09.014

Ding, T., \& Xiao, J. (2014). Estimation of building-related construction and demolition waste in Shanghai. J. Waste Manag. 34(11), 23272334. https://doi.org/10.1016/j.wasman.2014.07.029

Dizdaroglu, D. (2015). Developing micro-level urban ecosystem indicators for sustainability assessment. Environ. Impact Assess. 54, 119-124. https://doi.org/10.1016/j.eiar.2015.06.004

EEA. (2015). Urban Sustainability Issues-What Is a Resource-Efficient City?, (Technical report No 23/2015)

Erz, W. (1992). Wasteland: Land for conservation. BERG PUBLISHERS.

ESPON. (2013). EU-LUPA European Land Use Pattern. Executive Summary (Final Report).

European Commission. (2005). Thematic Strategy on the Sustainable Use of Natural Resources". Communication from the Commission to the Council, the European Parliament, the European Economic and Social Committee and the Committee of the Regions.

European Environment Agency. (2015). Urban sustainability issues: What is a resource-efficient city?. Publications Office. http://dx. publications.europa.eu/10.2800/389017.

Formato, E., \& Russo, M. (2014). Re-Use/Re-Cycle Territories: A Retroactive Conceptualisation for East Naples. TeMA - Journa of Land Use, Mobility and Environment, 431-440. https://doi. org/10.6092/1970-9870/2496

Franklin Associates. (1998). Characterization of Building-Related Construction and Demolition Debris in the United States (Report No. EPA530-R-98-010).

Gabbianelli, A. (2016). Metamorfosi degli spazi improduttivi. In L. Coccia \& A. Gabbianelli (Eds.), Riciclasi Capannoni. Aracne Editrice, 99-106. 
Gargari, C. (2015). Analisi e valutazione ambientale di un'area al margine del Parco. In M. C. Torricelli (Ed.), S-LCA e Patrimonio Naturale. Life Cicle Analisi Ambientale e Sociale Di Un'area Protetta (pp. 73-115). Firenze University Press.

Gargiulo Morelli, V., \& Salvati, L. (2010). Ad hoc urban sprawl in the mediterranean city: Dispersing a compact tradition? Nuova Cultura.

Gasparrini, C. (2016). DrossCity. Raccontare la città degli scarti. In Dross City. Metabolismo Urbano, Resilienza e Progetto Di Riciclo Dei Drosscape. List, 8-31.

Gasparrini, C., \& Terracciano, A. (2016). Dross City: Metabolismo urbano, resilienza e progetto di riciclo dei drosscape. List.

Geldermans, B., Bellstedt, C., Formato, E., Varju, V., Grunhut, Z., Cerreta, M., Amenta, L., Inglese, P., van der Leer, J., \& Wandl, A. (2017). D3.1 Introduction to methodology for integrated spatial, material flow and social analyses (REPAiR Deliverable D3.1.).

Geldermans, B., Wandl, A., Steenmeijer, M., Furlan, C., Streefland, T., Formato, E., Cerreta, M., Amenta, L., Inglese, P., lodice, S., Berruti, G., Varju, V., Grunhut, Z., Bodor, A., Lovász, V., Moticska, Z., Tonini, D., Taelman, S. E. (2018). D3.3 Process model for the two pilot cases: Amsterdam, the Netherlands \& Naples, Italy. (REPAiR Deliverable D3.3.).

Ghosh, S. K., Haldar, H. S., Chatterjee, S., \& Ghosh, P. (2016). An Optimization Model on Construction and Demolition Waste Quantification from Building. Sci. 35, 279-288. https://doi.org/10.1016/j. proenv.2016.07.008

Gonçalves, J., Gomes, M., \& Ezequiel, S. (2017). Defining mobility patterns in peri-urban areas: A contribution for spatial and transport planning policy. Case Studies on Transport Policy 5(4), 643-655. https://doi.org/10.1016/j.cstp.2017.07.009.

Hauschild, M. Z., \& Huijbregts, M. A. J. (2015). Introducing Life Cycle Impact Assessment. In M. Z. Hauschild \& M. A. J. Huijbregts (Eds.), Life Cycle Impact Assessment. Springer Netherlands, 1-16. https://doi.org/10.1007/978-94-017-9744-3_1

Helling, R. K. (2017). The Role of LCA in Sustainable Development. In Encyclopedia of Sustainable Technologies, 237-242. Elsevier. https://doi.org/10.1016/B978-0-12-409548-9.10063-6.

Kennedy, C., Cuddihy, J., \& Engel-Yan, J. (2007). The Changing Metabolism of Cities. J. Ind. Ecol. 11(2), 43-59. https://doi.org/10.1162/ jie.2007.1107.

Kofoworola, O. F., \& Gheewala, S. H. (2009). Estimation of construction waste generation and management in Thailand. J. Waste Manag. 29(2), 731-738. https://doi.org/10.1016/j.wasman.2008.07.004.

Li, H., \& Kwan, M.-P. (2018). Advancing analytical methods for urban metabolism studies. RESOUR CONSERV RECY 132, 239-245. https://doi.org/10.1016/j.resconrec.2017.07.005.

Loiseau, E., Aissani, L., Le Féon, S., Laurent, F., Cerceau, J., Sala, S., \& Roux, P. (2018). Territorial Life Cycle Assessment (LCA): What exactly is it about? A proposal towards using a common terminology and a research agenda. J. Clean. Prod. 176, 474-485. https://doi. org/10.1016/j.jclepro.2017.12.169.

Loiseau, E., Junqua, G., Roux, P., \& Bellon-Maurel, V. (2012). Environmental assessment of a territory: An overview of existing tools and methods. J ENVIRON MANAGE 112, 213-225. https://doi. org/10.1016/j.jenvman.2012.07.024

Loiseau, E., Roux, P., Junqua, G., Maurel, P., \& Bellon-Maurel, V. (2013). Adapting the LCA framework to environmental assessment in land planning. INT J LIFE CYCLE ASS 18(8), 1533-1548. https://doi. org/10.1007/s11367-013-0588-y.

Loiseau, E., Roux, P., Junqua, G., Maurel, P., \& Bellon-Maurel, V. (2014) Implementation of an adapted LCA framework to environmental assessment of a territory: Important learning points from a French Mediterranean case study. J. Clean. Prod. 80, 17-29. https://doi. org/10.1016/j.jclepro.2014.05.059.

Lynch, K., \& Southworth, M. (1990). Wasting away. Sierra Club Books.

Maranghi, S., Parisi, M. L., Facchini, A., Rubino, A., Kordas, O., \& Basosi, R. (2020). Integrating urban metabolism and life cycle assessment to analyse urban sustainability. Ecol. Indic. 112, 106074. https:// doi.org/10.1016/j.ecolind.2020.106074.

Martínez Lage, I., Martínez Abella, F., Herrero, C. V., \& Ordóñez, J. L. P. (2010). Estimation of the annual production and composition of C\&D Debris in Galicia (Spain). J. Waste Manag. 30(4), 636-645. https://doi.org/10.1016/j.wasman.2009.11.016

Marx, K. (1909). Capital: A Critique of Political Economy (Vol. 1). Frederick Engels
Mazzeo, G., \& Russo, L. (2016). Aspects of Land Take in the Metropolitan Area of Naples. TeMA - Journal of Land Use, Mobility and Environment 9(1), 89-107. https://doi.org/10.6092/1970-9870/3727

McDonough, W., \& Braungart, M. (2002). Cradle to cradle: Remaking the way we make things (1st ed). North Point Press.

McPhearson, T., Pickett, S. T. A., Grimm, N. B., Niemelä, J., Alberti, M., Elmqvist, T., Weber, C., Haase, D., Breuste, J., \& Qureshi, S. (2016). Advancing Urban Ecology toward a Science of Cities. BioScience, 66(3), 198-212. https://doi.org/10.1093/biosci/biw002

Miano, P. (2005). La formazione dei nuovi luoghi centrali: II recupero delle aree dismesse di Casoria. Edizioni Scientifiche Italiane.

Minx, J., Creutzig, F., Medinger, V., Ziegler, T., Owen, A., \& Baiocchi, G. (2010). Developing a Pragmatic Approach To Assess Urban Metabolism in Europe-A Report to the European Environment Agency. (Working Paper 01|2011). Technische Universität Berlin and Stockholm Environment Institute.

Mostafavi, N., Farzinmoghadam, M., \& Hoque, S. (2014). A framework for integrated urban metabolism analysis tool (IUMAT). BUILD ENVIRON 82, 702-712. https://doi.org/10.1016/j.buildenv.2014.10.020.

OECD. (2010). OECD Global Forum on Environment: Sustainable Materials Management. www.oecd.org/env/waste/oecdglobalforumonenvironmentsustainablematerialsmanagement.htm.

OECD. (2012). Sustainable Materials Management: Making Better Use of Resources. https://doi.org/10.1787/9789264174269-en.

Pérez-Soba, M., Petit, S., Jones, L., Bertrand, N., Briquel, V., Omodei-Zorini, L., Contini, C., Helming, K., Farrington, J. H., Mossello, M. T., Wascher, D., Kienast, F., \& de Groot, R. (2008). Land use functions-A multifunctionality approach to assess the impact of land use changes on land use sustainability. In K. Helming, M. Pérez-Soba, \& P. Tabbush (Eds.), Sustainability Impact Assessment of Land Use Changes. Springer, Berlin, 375-404. Heidelberg. https://doi. org/10.1007/978-3-540-78648-1_19

Phillis, Y. A., Kouikoglou, V. S., \& Verdugo, C. (2017). Urban sustainability assessment and ranking of cities. COMPUT ENVIRON URBAN, 64, 254-265. https://doi.org/10.1016/j.compenvurbsys.2017.03.002.

Redman, C. L., Grove, J. M., \& Kuby, L. H. (2004). Integrating Social Science into the Long-Term Ecological Research (LTER) Network: Social Dimensions of Ecological Change and Ecological Dimensions of Social Change. Ecosystems 7(2). https://doi.org/10.1007/ s10021-003-0215-z.

Rees, W. E. (1997). Urban ecosystems: The human dimension. Urban Ecosyst. 1(1),63-75 https://doi.org/10.1023/A:1014380105620.

Rees, W. E. (2017). Ecological Footprints and Appropriated Carrying Capacity: What Urban Economics Leaves Out. Urbanisation, 2(1), 66-77. https://doi.org/10.1177/2455747117699722

Rees, W., \& Wackernagel, M. (1996). Urban ecological footprints: Why cities cannot be sustainable-And why they are a key to sustainability. Environ. Impact Assess. 16(4-6), 223-248. https://doi. org/10.1016/S0195-9255(96)00022-4

Strasser, S. (1992). Waste and want: The other side of consumption. BERG PUBLISHERS.

Su, M., Yang, Z., Chen, B., Liu, G., Zhang, Y., Zhang, L., Xu, L., \& Zhao, Y. (2012). Urban Ecosystem Health Assessment and Its Application in Management: A Multi-Scale Perspective. Entropy, 15(1), 1-9. https://doi.org/10.3390/e15010001

Taelman, S. E., Tonini, D., \& Wandl, A. (2017). D4.2 Preliminary Sustainability Framework Ready for Testing the GDSE (REPAiR Deliverable D4.2).

Taelman, S., Sanjuan-Delmás, D., Tonini, D., \& Dewulf, J. (2019). An operational framework for sustainability assessment including local to global impacts: Focus on waste management systems. RESOUR CONSERV RECY 2, 100005. https://doi.org/10.1016/j. rcrx.2019.100005

Tansley, A. G. (1935). The Use and Abuse of Vegetational Concepts and Terms. Ecology, 16(3), 284-307. https://doi.org/10.2307/1930070

Threlfall, C. G., \& Kendal, D. (2018). The distinct ecological and social roles that wild spaces play in urban ecosystems. URBAN FOR URBAN GREE 29, 348-356. https://doi.org/10.1016/j. ufug.2017.05.012

Tonini, D., Iodice, S., Wandl, A., Meister, K., Munoz Uceta, P., Taelman, S. E., San-Juan Delmas, D., \& De Toro, P. (n.d.). D4.6 Sustainability assessment for the pilot case studies-Part A: Status Quo (REPAiR Deliverable D4.6).

Torricelli, M.C. (2015a). Contesto ed obiettivi della ricerca. In M. C. Torricelli (Ed.), S-LCA e Patrimonio Naturale. Life Cicle Analisi Ambientale e Sociale Di Un'area Protetta (pp. 73-115). Firenze University Press. 
Torricelli, M.C. (2015b). ES-LCA e Patrimonio Naturale Life Cicle Analisi Ambientale e Sociale Di Un'area Protetta. Firenze University Press, Florence.

Torricelli, M. C., \& Gargari, C. (2015). Sostenibilità ambientale e sociale di un territorio naturale protetto. In M. C. Torricelli (Ed.), S-LCA e Patrimonio Naturale. Life Cicle Analisi Ambientale e Sociale Di Un'area Protetta (pp. 59-70). Firenze University Press.

Turconi, R., Butera, S., Boldrin, A., Grosso, M., Rigamonti, L., \& Astrup, T. (2011). Life cycle assessment of waste incineration in Denmark and Italy using two LCA models. Waste Manag. Res. 29(10_suppl), S78-S90. https://doi.org/10.1177/0734242X11417489.

UNEP (Ed.). (2011). Decoupling natural resource use and environmental impacts from economic growth.

Verburg, P. H., van de Steeg, J., Veldkamp, A., \& Willemen, L. (2009). From land cover change to land function dynamics: A major challenge to improve land characterization. J ENVIRON MANAGE 90(3), 1327-1335. https://doi.org/10.1016/j.jenvman.2008.08.005.
Wimalasena, B. A. D. S., Ruwanpura, J. Y., \& Hettiaratchi, J. P. A. (2010). Modeling Construction Waste Generation towards Sustainability. Construction Research Congress 2010, 1498-1507. https://doi. org/10.1061/41109(373)150.

Wolman, A. (1965). Scientific American. The Metabolism of Cities, 179-190.

Wu, Z., Yu, A. T. W., Shen, L., \& Liu, G. (2014). Quantifying construction and demolition waste: An analytical review. J. Waste Manag. 34(9), 1683-1692. https://doi.org/10.1016/j.wasman.2014.05.010

Zhu, Y.-G., Reid, B. J., Meharg, A. A., Banwart, S. A., \& Fu, B.-J. (2017). Optimizing Peri-URban Ecosystems (PURE) to re-couple urban-rural symbiosis. Sci. 586, 1085-1090. https://doi.org/10.1016/j.scitotenv.2017.02.094.

Zucchetti, S. (2008) IL MARKETING TERRITORIALE: UNA LEVA PER LO SVILUPPO? Liuc Papers, 214(Serie Economia e Istituzioni 21).

${ }^{1}$ Information about REPAiR Project are available at: http://h2020repair.eu/ ${ }^{2}$ Figure elaborated by the authors for the Horizon 2020 REPAiR Deliverable 3.3 (Geldermans et al., 2018).

${ }^{3}$ The choice to adopt these indicators compared to others is due to the similarity of the Spanish context, in which the application is localized, compared to the Italian one.

${ }^{4}$ Dimensional measures about the Rhodiatoce industrial plant have been calculated trough the cartographic material kindly provided by Professor Pasquale Miano from the Department of Architecture of the University of Naples Federico II.

${ }^{5}$ It is necessary to bear in mind that the aim of this section is not that of calculating a precise amount, but that of developing a multi-scale methodology that could serve as an example. 